\title{
Toward Board Declassification in 100 S\&P 500 and Fortune 500 Companies: Report of the SRP for the 2012 and 2013 Proxy Seasons
}

\section{Citation}

Lucian Bebchuk, Scott Hirst \& June Rhee, Toward Board Declassification in 100 S\&P 500 and Fortune 500 Companies: Report of the SRP for the 2012 and 2013 Proxy Seasons (Harvard Law School Forum on Corporate Governance and Financial Regulation, Feb., 2014).

\section{Permanent link}

http://nrs.harvard.edu/urn-3:HUL.InstRepos:16882982

\section{Terms of Use}

This article was downloaded from Harvard University's DASH repository, and is made available under the terms and conditions applicable to Other Posted Material, as set forth at http:// nrs.harvard.edu/urn-3:HUL.InstRepos:dash.current.terms-of-use\#LAA

\section{Share Your Story}

The Harvard community has made this article openly available.

Please share how this access benefits you. Submit a story.

Accessibility 
The Shareholder Rights Project (SRP) is a clinical program operating at Harvard Law School and directed by Professor Lucian Bebchuk. The SRP works on behalf of public pension funds and charitable organizations seeking to improve corporate governance at publicly traded companies, as well as on research and policy projects related to corporate governance. Any views expressed and positions taken by the SRP and its representatives should be attributed solely to the SRP and not to Harvard Law School or Harvard University.

\section{Toward Board Declassification in 100 S\&P 500 and Fortune 500 Companies: Report of the SRP for the 2012 and 2013 Proxy Seasons}

February 2014

Lucian Bebchuk, ${ }^{*}$ Scott Hirst,** and June Rhee***

* William J. Friedman and Alicia Townsend Friedman Professor of Law, Economics, and Finance, Harvard Law School. ${ }^{* *}$ Lecturer on Law, Harvard Law School. ${ }^{* * *}$ Fellow, Harvard Law School. The authors serve as Director, Associate Director, and a counsel, respectively, of the Shareholder Rights Project (SRP) 


\section{$\underline{\text { Executive Summary }}$}

This report provides an overview and analysis of the work that the Shareholder Rights Project (SRP) undertook on behalf of a number of institutional investors during 2012 and 2013, the SRP's first two years of operations. During 2012 and 2013, the SRP worked on behalf of eight SRP-represented investors on board declassification proposals submitted for a vote at the 2012 and/or 2013 annual meetings of 122 S\&P 500 and Fortune 500 companies, and this work has produced substantial results:

100 Negotiated Outcomes: Negotiated outcomes involving a commitment to board declassification were reached with 100 S\&P 500 and Fortune 500 companies, about three-quarters of the companies receiving proposals in 2012 and/or 2013.

58 Successful Precatory Proposals: During 2012 and 2013, declassification proposals brought by SRP-represented investors received majority support at 58 annual meetings of 53 S\&P 500 and Fortune 500 companies (all but three of the annual meetings in which such proposals went to a vote), with average support of about $80 \%$ of votes cast.

81 Board declassifications: A total of 81 S\&P 500 and Fortune 500 companies already declassified their boards during 2012 and 2013 as a result of the work of the SRP and SRP-represented investors. These 81 companies, which have an aggregate market capitalization exceeding one trillion dollars (as of Dec, 31, 2013), represent about 65\% of the companies with which engagements took place and about $60 \%$ of the S\&P 500 companies that had classified boards as of the beginning of 2012 .

Expected Impact by End of 2014: The work of the SRP and SRP-represented investors is expected to produce a significant number of additional board declassifications during 2014 as a result of (i) management declassification proposals that will go to a vote pursuant to 2012 and 2013 agreements, (ii) companies agreeing to follow the preferences of shareholders expressed in 58 successful precatory declassification proposals, and (iii) ongoing engagement by the SRP and SRP-represented investors. We estimate that, by the end of 2014, this work will have contributed to movements towards board declassification by about 100 S\&P 500 and Fortune 500 companies; this large-scale change can be expected to increase board accountability and thereby to enhance shareholder value and company performance in the affected companies.

Beyond Board Declassification: The SRP's 2012 and 2013 work also facilitated a substantial increase in successful engagement by public pension funds, and in their ability to obtain governance changes favored by shareholders. The proposals that the SRP worked in 2012 and 2013 on represented over 50\% of the shareholder proposals by public pension funds that received majority support in 2012 and 2013, and over $20 \%$ of all precatory shareholder proposals (by all proponents) that received majority support in 2012 and 2013. 


\section{Table of Contents}

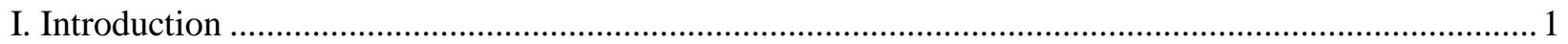

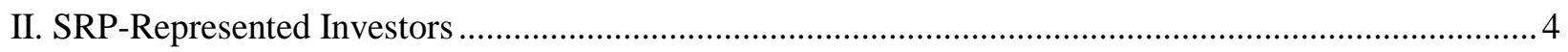

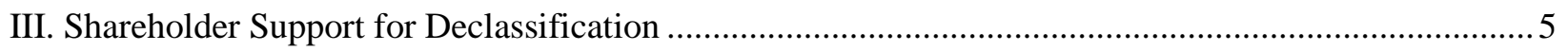

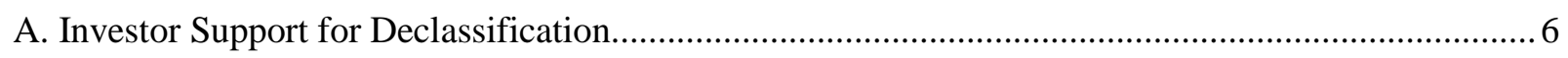

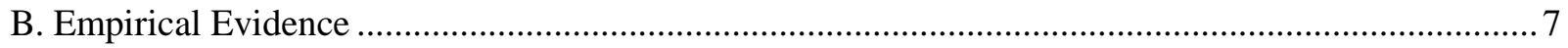

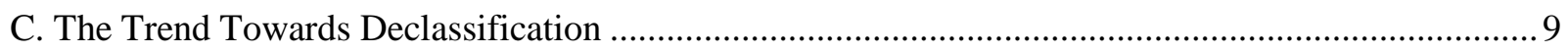

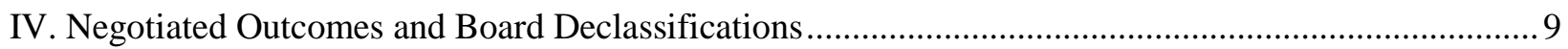

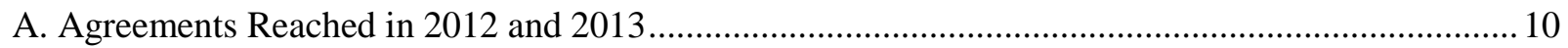

B. Companies Declassified Following 2012 and 2013 Agreements .................................................. 10

C. Additional Management Proposals to be Brought Pursuant to 2012 and 2013 Agreements.............. 13

D. Companies Declassified in Following 2011 Agreements with SRP-represented Investors............... 13

E. Companies Declassified Following Successful 2012 Precatory Proposals ..................................... 14

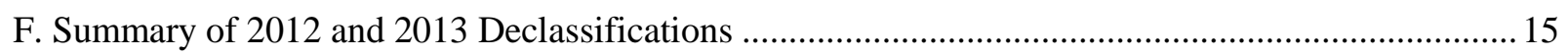

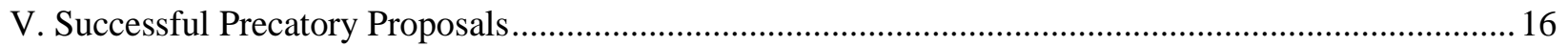

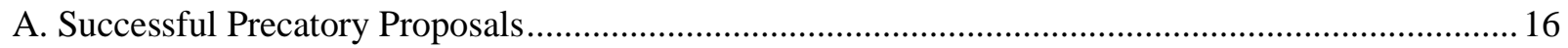

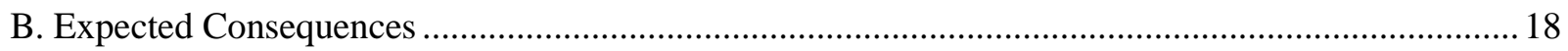

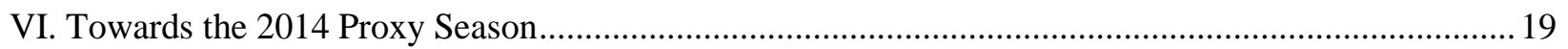

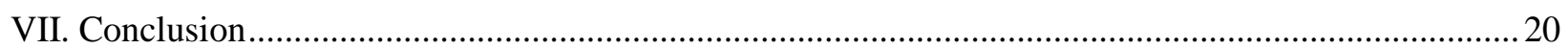

Appendix A: Outcomes of All 2012 \& 2013 Proposals by Company ….................................................. 22

Appendix B: Outcomes of All 2012 \& 2013 Proposals by Proponent....................................................... 36 


\section{Introduction}

This report reviews and analyzes the activities of the Shareholder Rights Project (SRP) in 2012 and 2013, the SRP's first two years of operations. In 2012 and 2013, the SRP worked on behalf of SRPrepresented investors in connection with 165 declassification proposals submitted to 122 S\&P 500 and Fortune 500 companies with classified boards for a vote at the companies' 2012 or 2013 annual meetings. ${ }^{1}$ The SRP provided SRP-represented investors with a range of services in connection with the submission of shareholder proposals, including submitting proposals on behalf of such investors, assisting such investors in connection with designing proposals, engaging with companies, negotiating and executing agreements with companies to bring management declassification proposals, and presenting proposals at annual meetings.

We are particularly pleased about three significant features of the outcomes produced by the 2012 and 2013 work of the SRP and SRP-represented investors on board declassification proposals. First, companies receiving proposals were responsive to the engagement efforts of the SRP and SRPrepresented investors, with about three-quarters of the companies receiving proposals in 2012 and/or 2013 agreeing to move towards annual elections.

Second, the overwhelming majority of the 61 precatory proposals that went to a vote passed, generally by large margins. These successful precatory proposals are expected to lead to a significant number of additional declassifications.

Third, the SRP's work has already contributed to bringing about a major reduction in the number of board classification among S\&P 500 companies. This work is expected to contribute to a further significant decrease in the number of board classifications in 2014.

Beyond its impact on board declassification, the 2012 and 2013 work of the SRP contributed to a substantial increase in the number of successful engagements by public pension funds, and enhanced the ability of such investors to bring about changes supported by shareholders. Proposals that the SRP worked on represented over $50 \%$ of the shareholder proposals by public pension funds that received majority support in 2012 or 2013; and over 20\% of all precatory shareholder proposals (by all proponents) that received majority support in 2012 or 2013.

\footnotetext{
${ }^{1}$ The SRP also worked on four additional proposals during 2012 and 2013 that, for technical reasons, were either withdrawn without any agreement being reached with the companies or not presented at the annual meeting.
} 
This report is organized as follows. Part II provides information on each of the eight institutional investors with which the SRP is working. The SRP-represented investors include seven public pension funds and one foundation. These investors serve more than three million members, and the aggregate value of assets that they manage exceeds $\$ 400$ billion.

Part III discusses the value of board declassification, and the widespread support for declassification among investors. ${ }^{2}$ SRP-represented investors have proxy-voting guidelines opposing classified boards, as do most other institutional investors. The widespread investor opposition to classified boards is consistent with empirical studies documenting an association between classified boards and undesirable outcomes for shareholders. Over the last 15 years, issuer responsiveness to investor preferences has produced a continuing decline of the number of S\&P 500 companies with classified boards. The 2012 and 2013 work of the SRP and SRP-represented investors has accelerated this trend significantly.

Part IV describes the negotiated outcomes and the board declassifications resulting from work by the SRP and SRP-represented investors. Engagement with companies receiving board declassification proposals resulted in negotiated outcomes with 100 S\&P 500 and Fortune 500 companies. Following the agreements these 100 companies entered into with SRP-represented investors, 87 of these companies brought management proposals to declassify for shareholder approval at 2012 or 2013 annual meetings, seven committed to doing so at subsequent annual meetings, five companies implemented bylaw amendments (where a company's classified board structure is set out in its bylaws, it may declassify without a shareholder vote), and one company declassified through a merger. ${ }^{3}$

Part IV also discusses the scale of board declassifications taking place during 2012 and 2013 among S\&P 500 and Fortune 500 companies as a result of work by the SRP and SRP-represented investors. This work resulted in 81 declassifications during 2012 and 2013: 35 declassifications during

\footnotetext{
${ }^{2}$ The value of board declassification and the work by the SRP and SRP-represented investors to enable shareholders to register their support for declassification are described in Lucian Bebchuk, Giving Shareholders a Voice, New York Times DealBook, April 19, 2012, available at http://dealbook.nytimes.com/2012/04/19/giving-shareholders-a-voice/; see also Lucian Bebchuk, Wachtell Lipton Was Wrong About the Shareholder Rights Project, Harvard Law School Forum on Corporate Governance and Financial Regulation, April 9, 2013, available at http://blogs.law.harvard.edu/corpgov/2013/04/09/wachtell-lipton-was-wrong-about-the-shareholderrights-project/.

${ }^{3}$ The company agreed to declassify, and the declassification took place through a merger, with the surviving corporation having directors elected annually.
} 
2012; ${ }^{4}$ seven declassifications resulting from the passage at 2012 annual meetings of management proposals to declassify brought following 2011 agreements with SRP-represented investors; and 39 declassifications during 2013. Altogether, the 81 S\&P 500 companies whose boards were declassified during 2012 and 2013 as a result of work by the SRP and SRP-represented investors have a market capitalization exceeding one trillion dollars (as of December 31, 2013), and represent about 65\% of the 122 S\&P 500 and Fortune 500 companies with which the SRP and SRP-represented investors engaged. Furthermore, these board declassifications reduced the incidence of classified boards among S\&P 500 companies as of the beginning of 2012 by more than $50 \% .^{5}$

Part V discusses the 61 precatory proposals that went to a vote at S\&P 500 and Fortune 500 companies where the efforts of the SRP and SRP-represented investors to obtain a negotiated outcome did not succeed. Out of these 61 proposals, 58 proposals passed (95\%) and only three proposals did not pass. Moreover, the proposals that passed did so by large margins, with average support of more than $80 \%$ of the votes cast.

Finally, Part VI concludes by discussing the impact that the work of the SRP and SRPrepresented investors is expected to have on the number of classified boards among S\&P 500 and Fortune 500 companies by the end of 2014. We expect to see further movement towards annual elections during 2014 as a result of the management declassification proposals that will go to a vote during that year pursuant to 2012 and 2013 agreements. We also expect a significant number of board declassifications to result from both (i) companies agreeing to follow the preferences of shareholders expressed in the 58 successful precatory declassification proposals in 2012 and 2013, and (ii) the ongoing engagement by the SRP and SRP-represented investors. We estimate that, by the end of 2014, this work will have contributed to movements toward board declassification by about 100 S\&P 500 and Fortune 500.

Appendix A to this report provides a full list of the outcomes and the current status of the engagements where SRP-represented investors submitted shareholder proposals for 2012 or 2013 annual

\footnotetext{
${ }^{4}$ As will be explained in Part IV, Section B, out of the 38 management proposals brought to a vote following 2012 agreements, 6 received majority support but failed to be approved due to the presence of $80 \%$ supermajority requirements. Three companies declassified following successful 2012 precatory proposals through bylaw amendments (where company's classified board structures are set out in its bylaws, it may declassify without a shareholder vote).

${ }^{5}$ The number of classified boards among S\&P 500 companies at the beginning of 2012 is taken from Factset Research Systems, Inc., Classified Boards Year Over Year, SHARKREPELlent. http://sharkrepellent.net (last visited January 5, 2014).
} 
meetings. Appendix B provides lists of the outcomes and current status of the proposals submitted by each of the SRP-represented investors.

\section{SRP-Represented Investors}

The SRP has been working on behalf of eight institutional investors - the Florida State Board of Administration (SBA), the Illinois State Board of Investment (ISBI), the Los Angeles County Employees Retirement Association (LACERA), the Massachusetts Pension Reserves Investment Management Board (PRIM), the Nathan Cummings Foundation (NCF), the North Carolina Department of State Treasurer (NCDST), the Ohio Public Employees Retirement System(OPERS), and the School Employees Retirement System of Ohio (SERS). As explained below, the SRP worked with six of these SRP-represented investors in connection with shareholder declassification proposals for the 2012 annual meetings, and worked with all eight SRP-represented investors in connection with such proposals for 2013 meetings. Detailed information about these institutional investors is provided below.

ISBI is a non-appropriated state agency that is responsible for managing and investing the pension assets of the Illinois General Assembly Retirement System, the Judges’ Retirement System of Illinois and the State Employees' Retirement System of Illinois. ISBI managed assets with a value exceeding \$13 billion as of August 31, 2013.

LACERA, the largest county retirement system in the United States, administers and manages the retirement fund for employees and retirees of Los Angeles County and its outside districts, and their beneficiaries. LACERA managed assets with a value exceeding \$38 billion and provided retirement benefits and savings for more than 148,000 members as of June 30, 2012.

The NCF is a charitable foundation and an institutional shareholder, and submits shareholder resolutions on issues that lie at the intersection of its programmatic interests and long-term shareholder value.

The NCDST is the fiduciary for the North Carolina Retirement Systems (NCRS). NCRS managed assets with a value exceeding $\$ 80$ billion, and provided retirement benefits and savings for more than 875,000 North Carolinians, including teachers, state employees, firefighters, police officers, and other public workers, as of June 30, 2013.

OPERS, the largest public pension fund in Ohio and the 11th largest public pension fund in the U.S, managed assets with a value exceeding $\$ 80$ billion, and provided retirement benefits and savings for more than a million members. 
PRIM is charged with the general supervision of the Pension Reserves Investment Trust (PRIT) Fund, with pension assets exceeding \$53 billion and serving more than 280,000 members. The PRIT Fund is a pooled investment fund that invests the assets of the Massachusetts Teachers' and State Employees' Systems, and the assets of county, authority, district, and municipal retirement systems that choose to invest in the PRIT Fund.

The SBA is an agency of Florida state government that provides a variety of investment services to various governmental entities. These include managing the assets of the Florida Retirement System Trust Fund (FRS), the Lawton Chiles Endowment Fund, the Local Government Surplus Funds Trust Fund, the Hurricane Catastrophe Fund, and a variety of other mandates. The SBA manages assets with a total value exceeding $\$ 168$ billion and the FRS provides pension benefits to almost one million beneficiaries and retirees.

SERS is a statewide public pension fund that provides pension benefits and access to postretirement health care for non-teaching public school employees in Ohio. SERS provides retirement security for administrative assistants, bus drivers, food service workers, librarians, maintenance personnel, teacher aides, and treasurers. SERS' mission is to provide its 190,000+ members, retirees, and beneficiaries with pension benefit programs and services that are soundly financed, prudently administered, and delivered with understanding and responsiveness. On June 30, 2012, SERS managed assets of $\$ 11$ billion.

Overall, the eight SRP-represented investors hold assets with an aggregate value exceeding \$400 billion and serve over three million members.

\section{Shareholder Support for Declassification}

Declassification of boards of directors enables shareholders to register their views on the performance of all directors at each annual meeting. Having directors stand for elections annually makes directors more accountable to shareholders, and could thereby contribute to improving performance and increasing firm value. Annual election of the boards of directors is widely viewed as corporate governance best practice.

Section A of this Part III describes the support among SRP-represented investors, as well as institutional investors more broadly, for declassification. Section B explains how the strong investor opposition to classified boards is consistent with empirical studies. Finally, Section C discusses the trend towards declassification. 


\section{A. Investor Support for Declassification}

There is a clear and widespread opposition to classified boards among institutional investors. In particular, SRP-represented investors have proxy voting policies that express their preference for annual elections and their support for declassifications proposals. This is the case for each of the SBA, LACERA, PRIM, the NCF, the NCDST and OPERS. ${ }^{6}$

In this respect, SRP-represented investors have similar views to those of other institutional investors. For example, the American Funds, BlackRock, CalPERS, Fidelity, TIAA-CREF and Vanguard, all have policies that support annual election of all directors and voting in favor of board declassification proposals. ${ }^{7}$ In addition, the Council of Institutional Investors has a similar policy. ${ }^{8}$ ISS and Glass Lewis,

6 See The Florida State Board of Administration, Corporate Governance Principles \& Proxy Voting Guidelines(2012),

[http://www.sbafla.com/fsb/LinkClick.aspx?fileticket=KY96Es7W718\%3d\&tabid=1441\&mid=3927]

("The SBA opposes classified boards and their provisions ... Alternatively, the SBA supports changing from a staggered board structure to annual elections for all directors.”); Los Angeles County Employees Retirement Association, Domestic Proxy Voting Guidelines (April 22, 2009), Section III.A.1 ("LACERA votes for proposals to repeal classified boards and to elect all directors annually.”); Pension Reserves Investment Management Board, Proxy Voting Guidelines-2012, p.15 ("Vote FOR shareholder proposals to repeal classified (staggered) boards, and to elect all directors annually.”); The Nathan Cummings Foundation, Proxy Voting Practices (February 2012), p.3 ("The Foundation will vote FOR proposals requesting the declassification of the board.”); North Carolina Department of State Treasurer, Proxy Voting Guidelines, Section III.A. ("All directors should be elected on an annual basis. The NCSRP will vote FOR shareholder resolutions that ask companies to declassify their boards.”); Ohio Public Employees Retirement System, Proxy Voting Guidelines (December 2012), Section IV.1.C.v.a. ("It is considered a best practice to have all directors elected on an annual basis to enhance accountability and to better align the board's interests with those of long-term shareowners.").

7 American Funds, Proxy Voting Procedures and Principles (May 2013), p.3 [https://www.americanfunds.com/pdf/proxy_voting_guidelines.pdf] ("Generally, we support proposals declassifying boards.”); BlackRock Inc., 2012 Proxy Voting Guidelines for U.S. Securities (March 2012), p.5 ("Therefore, we typically vote ... for proposals to eliminate board classification.”); California Public Employees' Retirement System, Global Principles of Accountable Corporate Governance (November 2011), Section 2.1 (“All directors should be elected annually.”); Fidelity Investments, Fidelity Funds' Proxy Voting Guidelines (November 2012), Section V.D. [http://personal.fidelity.com/myfidelity/InsideFidelity/InvestExpertise/governance.shtml\#fulltext] ("In the case of proposals to declassify a board of directors, FMR [Fidelity Management and Research] will generally vote against such a proposal if the issuer's Articles of Incorporation or applicable statutes include a provision whereby a majority of directors may be removed at any time, with or without cause, by written consent, or other reasonable procedures, by a majority of shareholders entitled to vote for the 
the two leading proxy advisors, also have policies of recommending voting in favor of proposals to dismantle classified boards. ${ }^{9}$

The widespread shareholder support for declassification is reflected in the results of the large number of precatory declassification proposals submitted by SRP-represented investors that went to a vote during 2012 and 2013. As will be discussed in detail in Part V, these proposals overwhelmingly passed, generally by large majorities.

\section{B. Empirical Evidence}

The significant shareholder support for declassification proposals is consistent with empirical studies reporting that classified boards are associated with lower firm value and inferior outcomes for shareholders. The first empirical study of classified boards, by Lucian Bebchuk, John Coates and Guhan Subramanian, focused on the effects of classified boards on the shareholders of takeover targets. ${ }^{10}$ The study concluded that classified boards were associated with lower gains for the shareholders of such targets.

A subsequent 2005 study by Lucian Bebchuk and Alma Cohen went beyond takeover targets to examine the effects of classified boards on the value of public companies in general. ${ }^{11}$ This study found that classified boards are associated with an economically meaningful reduction in firm value (as

election of directors.”); TIAA-CREF, Policy Statement on Corporate Governance (6th Ed.), Section B, Appendix A ("TIAA-CREF will generally support shareholder resolutions asking that each member of the board stand for re-election annually.”).

${ }^{8}$ See Council of Institutional Investors, Policies on Corporate Governance (April 2013), Section 2.1 (stating that "[a]ll directors should be elected annually. Boards should not be classified (staggered).”).

${ }^{9}$ Institutional Shareholder Services Inc., 2012 U.S. Proxy Voting Summary Guidelines (January 2012), p.17 [http://www.issgovernance.com/files/2012USSummaryGuidelines1312012.pdf] ("Vote FOR shareholder proposals to repeal classified boards and to elect all directors annually.”); Glass, Lewis \& Co., LLC, Proxy Paper Guidelines, 2012 Proxy Season, p.5 ("Glass Lewis favors the repeal of staggered boards in favor of the annual election of directors.”).

${ }^{10}$ Lucian A. Lucian A. Bebchuk, John C. Coates IV and Guhan Subramanian, The Powerful Antitakeover Force of Staggered Boards: Theory, Evidence, and Policy, 54 Stan. L. Rev. 887 (2002); see also Lucian Bebchuk, John Coates IV and Guhan Subramanian, The Powerful Antitakeover Force of Staggered Boards: Further Findings and a Reply to Symposium Participants, 55 Stan. L. Rev. 885 (2002).

${ }^{11}$ Lucian A. Bebchuk and Alma Cohen, The Costs of Entrenched Boards, 78 J. Fin. Econ. 409 (2005). 
measured by Tobin's Q). It also provided suggestive evidence that classified boards bring about (rather than merely reflect) an economically significant reduction in firm value.

The study's evidence of an association between classified boards and lower firm valuation has been subsequently confirmed by two additional studies - one by Olubunmi Faleye ${ }^{12}$ and the other by Michael Frakes. ${ }^{13}$ Furthermore, consistent with this evidence, a study of judicial rulings concerning the validity of shareholder-adopted bylaws that weaken the force of staggered boards, Alma Cohen and Charles Wang found that the stock market reactions accompanying these rulings reflected the market's belief that staggered boards bring about reduced firm value. ${ }^{14}$

Moreover, empirical work has identified particular dimensions of undesirable decisions-making that are associated with classified boards. A study by Ronald Masulis, Cong Wang, and Fei Xie demonstrated that firms with classified boards are more likely to be associated with undesirable acquisition decisions. ${ }^{15}$ The study examined stock market reactions to acquisition decisions and concluded that companies with classified boards are more likely to make acquisition announcements that are judged by the market to be value-reducing.

In addition, a study by Olubunmi Faleye found that classified boards are associated with worse compensation and executive retention decisions. ${ }^{16}$ The study showed that companies with classified boards provide executives with compensation that is less sensitive to performance, and exhibit lower sensitivity of CEO turnover to firm performance.

It is worth noting a study by David Bates, Thomas Becher and Michael Lemmon that has often been mentioned in statements of several companies opposing declassification proposals. ${ }^{17}$ The study

\footnotetext{
${ }^{12}$ Olubunmi Faleye, Classified Boards, Firm Value, and Managerial Entrenchment, 83 J. Fin. Econ. 501 (2007).

${ }^{13}$ Michael Frakes, Classified Boards and Firm Value, 32 Del. J. Corp. Law 113 (2007).

${ }^{14}$ Alma Cohen \& Charles C.Y. Wang, How Do Staggered Boards Affect Shareholder Value? Evidence from a Natural Experiment, J. Fin. Econ. (forthcoming), available at http://ssm.com/abstract=2141410.

${ }^{15}$ Ronald W. Masulis, Cong Wang and Fei Xie, Corporate Governance and Acquirer Returns, 62 J. Fin. 1851 (2007).

16 See Faleye, supra note 11.

${ }^{17}$ David Becher, Thomas W. Bates, and Michael L. Lemmon, Board Classification and Managerial Entrenchment: Evidence from the Market for Corporate Control, 87 J. Fin. Econ. 656 (2007). For examples of opposition statements relying on this study, see Board's Statement in Opposition to Proposal 4, contained in the Definitive Proxy Statement of United States Steel Corporation, filed on Schedule 14A
} 
found that classified boards are associated with higher takeover premiums. However, the study also reported that classified boards are associated with a lower likelihood of an acquisition and, most importantly, confirmed that, overall, classified boards are associated with lower firm valuation.

\section{The Trend Towards Declassification}

According to data from FactSet Research Systems, there were 303 S\&P 500 companies with classified boards at the beginning of 1999, and that number declined to 126 as of the beginning of $2012 .^{18}$ That is, during this twelve-period, the fraction of S\&P 500 companies with classified boards declined by about $60 \%$.

As explained in Parts IV and V, the work of the SRP and SRP-represented investors during 2012 and 2013 has contributed to a substantial acceleration of the trend towards board declassification among large public companies. The continuing work of the SRP and SRP-represented investors is expected to produce a further significant decline in the incidence of classified boards.

\section{Negotiated Outcomes and Board Declassifications}

This Part IV discusses the negotiated outcomes resulting from the work of the SRP and SRPrepresented investors during 2012 and 2013, as well as the board declassifications that have already resulted, or are expected to result, from these negotiated agreements. Section A provides an overview of the 100 successful engagements resulting in companies entering into agreements to move toward annual elections following the submission of board declassification proposals for 2012 and 2013 meetings. Section B discusses the 67 successful management declassification proposals and engagements that have already resulted in companies declassifying their boards of directors. Section $C$ focuses on the seven management proposals that have yet to be voted on. Section D discusses seven additional declassifications that took place during 2012 following 2011 agreements with SRP-represented investors.

(March 9, 2012), available at http://www.sec.gov/Archives/edgar/data/ 1163302/000119312512106628/d293423ddef14a.htm (last visited Nov. 12, 2012); and Board of Directors Response to Proposal 5, contained in the Definitive Proxy Statement of Urban Outfitters, Inc., filed on Schedule 14A (April 2, 2012), available at http://www.sec.gov/Archives/edgar/data/912615/000119312512145959/d317811ddef14a.htm (last visited Nov. 6, 2012).

${ }^{18}$ See Factset Research Systems, Inc., supra note 4. 
Section E discusses the four companies that declassified following successful 2012 precatory proposals submitted by SRP-represented investors. Finally, Section F puts the discussion of the preceding sections together to provide a summary of the 81 declassifications that took place during 2012 and 2013 due to the work of the SRP and SRP-represented investors.

\section{A. Agreements Reached in 2012 and 2013}

Through active engagements with companies receiving declassification proposals, the SRP and SRP-represented investors were able to reach negotiated outcomes with 100 companies receiving declassification proposals whereby the companies entered into agreements to move towards annual elections.

Overall, these 100 companies represent about three-quarters of the companies receiving proposals for their 2012 and/or 2013 annual meetings. Furthermore, these 100 companies represent about two-thirds of the 126 S\&P 500 companies that had classified boards as of the beginning of 2012. The aggregate market capitalization of these 100 companies (as of December 31, 2013) exceeded one trillion dollars. ${ }^{19}$ All of these companies should be commended for their responsiveness to shareholder concerns, and for their willingness to move to annual elections.

From the 100 agreements with companies to move towards annual elections, 90 agreed-upon management proposals have already been voted on by shareholders, resulting in the declassification of 67 companies, and seven management proposals will be voted on in the future. Sections B and C discuss, respectively, the companies that have declassified, and the companies where management proposals will go to a vote in the future.

\section{B. Companies Declassified Following 2012 and 2013 Agreements}

Agreed-upon management proposals to declassify have been voted on at 90 companies. Of these 90 proposals, 67 proposals have passed, resulting in the declassification of those companies' boards of directors. These 67 proposals received average support of $99 \%$ of votes cast and $81 \%$ of shares outstanding.

\footnotetext{
${ }^{19}$ See Factset Research Systems, Inc., Dataset, SHARKREPELLENT. http://sharkrepellent.net (last visited January 5, 2013).
} 
In addition to these 67 declassifications, at two companies (CIGNA Corporation, and Lincoln National Corporation), where the classified board structures were established in the companies' bylaws, after successful engagements with the companies, the board agreed to a declassification through a boardadopted amendment to the company's bylaws.

Table 1 below lists each of the 67 companies where boards were declassified following 2012 and 2013 agreements and the SRP-represented investors that submitted each declassification proposal.

\section{Table 1: Companies Declassified Following 2012 and 2013 Agreements With SRP-Represented Investors}

\section{Declassifications following}

2012 Agreements

Amphenol Corporation (NCF)

BlackRock, Inc. (ISBI )

C.H. Robinson Worldwide, Inc. (NCF)

C.R. Bard, Inc. (OPERS)

Cabot Oil \& Gas Corporation (NCDST)

Cameron International Corporation (NCDST)

CenturyLink, Inc. (ISBI )

CIGNA Corporation (OPERS)

Coventry Health Care, Inc. (ISBI)

DeVRY, Inc. (PRIM)

Fidelity National Information Services, Inc. (ISBI)

Flowserve Corporation (NCDST)

FMC Technologies, Inc. (NCDST)

Helmerich \& Payne (NCDST)

Hudson City Bancorp, Inc. (NCF)

Intuitive Surgical, Inc. (NCDST)

Janus Capital Group Inc. (NCDST)

JDS Uniphase Corporation (PRIM)

Juniper Networks, Inc. (ISBI)
Declassifications following

2013 Agreements

Best Buy Co, Inc. (NCF)

CareFusion Corporation (NCF)

CarMax, Inc. (NCF)

CF Industries Holdings, Inc. (LACERA)

Chipotle Mexican Grill, Inc. (ISBI)

Citrix Systems, Inc. (LACERA)

Cognizant Technology Solutions Corporation (LACERA)

Crown Castle International Corp. (SERS)

DENTSPLY International Inc. (LACERA)

Edwards Lifesciences Corporation (ISBI)

EQT Corporation (OPERS)

F5 Networks, Inc. (ISBI)

FLIR Systems, Inc. (NCF)

FMC Corporation (NCF)

GameStop Corp. (NCF)

Hess Corporation (NCDST)

Johnson Controls, Inc. (PRIM)

L-3 Communications Holdings Inc. (NCDST)

Lexmark International (NCDST) 
KLA-Tencor Corporation (PRIM)

McDonald's Corporation (LACERA)

Newell Rubbermaid Inc. (ISBI)

NRG Energy, Inc. (NCDST)

Owens-Illinois, Inc. (ISBI)

Patterson Companies, Inc. (PRIM)

Pioneer Natural Resources Company (LACERA)

TECO Energy, Inc. (NCF)

The Progressive Corporation (ISBI)

The Western Union Company (NCF)

Rowan Companies, Inc. (NCDST)

Stanley Black \& Decker, Inc. (NCDST)

Wyndham Worldwide Corporation (NCF)
Lincoln National Corporation (SERS)

Lorillard, Inc. (ISBI)

Manpower Inc. (SBA)

MetroPCS Communications, Inc. (LACERA)

Monsanto Company (PRIM)

Moody's Corporation (NCF)

NII Holdings, Inc. (SBA)

O'Reilly Automotive, Inc. (NCF)

People's United Financial, Inc. (NCDST)

Red Hat, Inc. (LACERA)

Roper Industries, Inc. (LACERA)

Ryder System, Inc. (NCDST)

salesforce.com, inc. (NCF)

Snap-On Inc. (NCDST)

The J. M. Smucker Company (LACERA)

Unum Group (LACERA)

United Natural Foods, Inc. (ISBI)

Xylem Inc. (NCF)

Of the 90 management declassification proposals that have been voted on, 21 proposals won a substantial majority (receiving average support of $94 \%$ of votes cast and $67 \%$ of shares outstanding) but did not pass due to the supermajority provisions requiring approval by $75 \%-85 \%$ of shares outstanding. The full details about these proposals can be found in the list of all outcomes provided by the Appendix. ${ }^{20}$

\footnotetext{
${ }^{20}$ These 21 management proposals that did not pass took place in 19 companies; in two companies, PPG Industries, Inc. and St. Jude Medical Inc., management declassification proposals did not pass the companies’ supermajority requirements twice, in both 2012 and 2013.
} 


\section{Additional Management Proposals to be Brought Pursuant to 2012 and 2013 Agreements}

As noted above, seven agreed-upon management proposals have yet to go to a vote. Of these proposals, one did not go to a vote during the 2013 proxy season due to a postponement of the company's 2013 annual meeting, and six will go to a vote in 2014. Table 2 below lists companies at which these proposals will go to a vote, and the SRP-represented investors that engaged with each company.

\section{Table 2: Additional Management Proposals to Be Brought}

Management Proposals Postponed from 2013

Tech Data Corporation (SERS)
Management Proposals to Be Brought in 2014

Allegheny Technologies Incorporated (OPERS)

Autoliv, Inc. (LACERA)

Centene Corporation (ISBI)

The Mosaic Company (OPERS)

Owens Corning (ISBI)

US Airways Group, Inc. (ISBI)

\section{Companies Declassified in 2012 Following 2011 Agreements with SRP-represented Investors}

In addition to the companies that declassified in 2012 as a result of the 2012 work of the SRP and SRP-represented investors, seven companies declassified in 2012 from the companies entering into agreements during 2011 with the SBA and the NCF, which worked with the American Corporate Governance Institute (ACGI) to submit shareholder proposals in $2011 .{ }^{21}$ In six cases, companies entered into agreements to bring agreed-upon management declassification proposals for approval at their 2012 annual meetings. In one case, the agreement required the company (eBay Inc.) to complete a full review of declassifying its board of directors within four months. Following this review, the company decided to bring a management proposal to declassify its board.

${ }^{21}$ For a description of this 2011 work, see Lucian Bebchuk and Scott Hirst, Contributing to the Declassification of 21 S\&P 500 Companies: Final Tally of the Results of the ACGI's 2011 Work, Harvard Law School Forum on Corporate Governance and Financial Regulation October 23, 2012, available at http://blogs.law.harvard.edu/corpgov/2012/10/23/contributing-to-the-declassification-of-21-sp-500companies-final-tally-of-the-results-of-the-acgis-2011-work/ 
Table 3 below lists the companies that declassified in 2012 following the 2011 agreements. For each company, Table 3 lists the SRP-represented investor that submitted the proposal to the company.

Table 3: Companies Declassified in 2012 Following 2011 Agreements With SRP-Represented Investors

CME Group Inc. (NCF)

Dean Foods Co (SBA)

Dr Pepper Snapple Group, Inc. (NCF)

E*Trade Financial Corporation (SBA)
eBay Inc. (NCF)

Fiserv, Inc. (SBA)

Hospira (NCF)

\section{E. Companies Declassified Following Successful 2012 Precatory Proposals}

In Part V, we discuss in detail the consequences of the many precatory proposals by SRPrepresented investors that passed during 2012. However, to provide a complete picture of the scale of board declassification among S\&P 500 and Fortune 500 companies during 2012 and 2013, we should also note the declassifications that took place as a result of successful precatory proposals. In particular, following the passage of such proposals at 2012 annual meetings, five companies heeded the expressed preferences of their shareholders - three by declassifying their boards through bylaw amendments and two by bringing management declassification proposals for shareholder approval at their 2013 annual meetings. In the three companies declassifying through bylaw amendments, the classified boards structure was established in the companies' bylaws (rather than the companies' charter), which made it possible for the board to declassify without having to bring a management proposal for shareholder approval at the next annual meeting.

Table 4 below lists these five companies that declassified through bylaw amendments and successful management declassification proposals following successful precatory proposals by SRPrepresented investors at 2012 meetings. For each company, Table 4 lists the SRP-represented investor that submitted the proposal to the company. We expect that the successful precatory proposals by SRPrepresented investors at 2013 meetings will similarly be followed in the future by a significant number of companies heeding the expressed preferences of their shareholders, resulting in additional board declassifications produced by the 2012 and 2013 work of the SRP and SRP-represented investors. 
Table 4: Companies Declassified Following

Successful Precatory Proposals by SRP-Represented Investors

Bemis Company (NCDST)

MEMC Electronic Materials, Inc. (NCDST)

Quest Diagnostics Incorporated (ISBI)
V.F. Corporation (NCF)

Urban Outfitters, Inc. (ISBI)

\section{F. Summary of 2012 and 2013 Declassifications}

Sections B, C, D, and E discussed board declassification taking place at S\&P 500 companies during 2012 and 2013 from three sources - following 2012 and 2013 engagement with the SRP and SRPrepresented investors and resulting agreements by companies to bring management proposals, following 2011 agreements with SRP-represented investors, and following 2012 successful precatory proposals by SRP-represented investors. Table 5 below aggregates the number of declassifications due to the 2012 and 2013 work of the SRP and SRP-represented investors.

\section{Total Declassifications}

\section{Source of Declassification}

Following 2012 and 2013 Agreements with SRP-represented Investors

Following 2011 Agreements with SRP-represented Investors

Following Successful 2012 Precatory Proposals

\section{Number of}

Declassification

69

7

5

Total
81

As the table indicates, the total number of board declassifications at S\&P 500 and Fortune 500 companies that took place in 2012 and 2013 as a result of work by SRP and SRP-represented investors was 81. Of the 81 companies declassifying their boards, 78 were S\&P 500 companies, more than half of the S\&P 500 companies that had classified boards at the beginning of 2012. Thus, the 2012 and 2013 board declassifications resulting from work by the SRP and SRP-represented investors has already brought about a major reduction in the incidence of board declassifications among S\&P 500 companies.

Furthermore, as Parts V and VI discuss below, the work of the SRP and SRP-represented investors is expected to contribute to a further decrease in the number of classified boards among S\&P 500 and Fortune 500 companies during 2014. This decrease is expected to result from the many 
successful precatory proposals discussed in Part V, as well as from the ongoing work of the SRP and SRP-represented investors discussed in Part VI.

\section{Successful Precatory Proposals}

Although the SRP and SRP-represented institutional investors were able to reach negotiated outcomes with 100 of the S\&P 500 and Fortune 500 companies receiving proposals, in many other cases they were not able to obtain negotiated agreements. As a result, 61 shareholder proposals urging board declassification have gone to a vote at the 2012 and/or 2013 annual meetings of 54 companies. In seven of the companies which did not agree to move to annual elections following the passage of a precatory declassification proposal in the 2012 annual meeting, declassification proposals by SRP-represented investors were also submitted in 2013, resulting in proposals being voted upon at the companies’ 2012 and 2013 annual meetings. Section A describes the high level of success enjoyed by the shareholder proposals, which overwhelmingly passed with strong majority support. Section B discusses the expected consequences of these successful proposals.

\section{A. Successful Precatory Proposals}

Altogether, SRP-represented investors have submitted shareholder proposals to 61 S\&P 500 and Fortune 500 companies where the SRP and SRP-represented investors were not able to reach negotiated outcomes. Shareholder proposal went to a vote in 41 companies during 2012, and 20 companies during 2013.

Of the 61 proposals that have gone to a vote, 58 proposals passed (95\% of the proposals that went to a vote). Three proposals narrowly failed to pass, one proposal at Kellogg Company in 2012 receiving support of 47.3\% of votes cast, and two proposals at PACCAR Inc. in 2012 and 2013 receiving support of $49.7 \%$ and $49.8 \%$ of votes cast, respectively. The 58 successful proposals that passed received large majorities, with average support of $81 \%$ of votes cast.

The work of the SRP and SRP-represented investors contributed substantially to the incidence of proposals that were successful in obtaining majority support. Proposals by SRP-represented investors on which the SRP worked represented 53\% of the precatory shareholder proposals by public pension funds 
that received majority support in 2012 and 2013. Furthermore, such proposals represented 21\% of the precatory shareholder proposals by all proponents that received majority support during 2012 and $2013 .{ }^{22}$

Table 5 below provides a list of the companies at which the 58 shareholder proposals were successful, together with the SRP-represented investor that submitted each shareholder proposal.

\section{Table 5: Successful Declassification Shareholder Proposals}

Shareholder Proposals in 2012

Airgas, Inc. (LACERA)

Apache Corporation (ISBI)

Baxter International Inc. (NCF)

Bemis Company (NCDST)

Best Buy Co, Inc. (NCF)

CareFusion Corporation (LACERA)

CarMax, Inc. (NCF)

Cerner Corporation (ISBI)

CF Industries Holdings, Inc. (LACERA)

Chipotle Mexican Grill, Inc. (ISBI)

Cognizant Technology Solutions

Corporation (LACERA)

DENTSPLY International Inc. (LACERA)

Edwards Lifesciences Corporation (ISBI)

EQT Corporation (OPERS)

F5 Networks, Inc. (ISBI)

FLIR Systems, Inc. (NCF)
Shareholder Proposals in 2013

Air Products and Chemicals, Inc. (PRIM)

Airgas, Inc. (LACERA)

Ashland Inc. (PRIM)

BorgWarner, Inc. (NCF)

Costco Wholesale Corporation (PRIM)

Foot Locker, Inc. (NCDST)

Huntsman Corporation (SBA)

Jacobs Engineering Group Inc. (PRIM)

Jarden Corporation (NCDST)

Kellogg Company (NCDST)

NCR Corporation (SBA)

Netflix, Inc. (SBA)

Rockwell Collins, Inc. (PRIM)

SCANA Corporation (SERS)

Teradata Corporation (NCDST)

United States Steel Corporation (NCDST)

\footnotetext{
${ }^{22}$ During 2012 and 2013, a total 278 precatory shareholder proposals received majority support, including 92 such proposals from public pension funds; 58 proposals from institutional investors working with the SRP (49 from public pension funds, nine from the Nathan Cummings Foundation) received majority support. See Factset Research Systems, Inc., Dataset, SHARKREPELLENT. http://sharkrepellent.net (last visited January 5, 2014).
} 
FMC Corporation (NCF)

Hess Corporation (NCDST)

Lexmark International, Inc. (NCDST)

Limited Brands, Inc. (ISBI)

Lorillard, Inc. (ISBI)

Masco Corporation (ISBI)

MEMC Electronic Materials, Inc. (NCDST)

Moody's Corporation (NCF)

Netflix, Inc. (LACERA)

People’s United Financial, Inc. (NCDST)

QEP Resources, Inc. (ISBI)

Quest Diagnostics Incorporated (ISBI)

Red Hat, Inc. (LACERA)

Ryder System, Inc. (NCDST)

salesforce.com, inc. (NCF)

SCANA Corporation (NCDST)

Snap-On Incorporated (NCDST)

The J. M. Smucker Company (LACERA)

United States Steel Corporation (NCDST)

Urban Outfitters, Inc. (ISBI)

V.F. Corporation (NCF)

Vornado Realty Trust (ISBI)

Vulcan Materials Company (ISBI)
Varian Medical Systems, Inc. (PRIM)

Vornado Realty Trust (ISBI)

WESCO International, Inc. (LACERA) 
boards of these companies will decide to follow the shareholder preferences expressed in these votes. At the time this report was finalized, the board of six such companies - Air Products and Chemicals, Inc., Ashland Inc., Costco Wholesale Corporation, Jacobs Engineering Group Inc., Rockwell Collins, Inc. and Varian Medical Systems, Inc. - had already publicly announced moves in the direction recommended by its shareholders.

We also expect significant movement towards board declassification among other companies where precatory declassification proposals passed at 2013 annual meetings. The passage of proposals with substantial majorities makes it likely that many of these companies will also follow the clearly-expressed preferences of their shareholders and put forward management proposals to declassify at their 2014 annual meetings. Furthermore, the SRP and SRP-represented investors continue their ongoing engagement with these companies to increase the likelihood of this outcome and, on the basis of this engagement, we expect that a substantial proportion of these companies will move towards annual elections.

\section{Towards the 2014 Proxy Season}

Overall, as explained in Part IV, work by the SRP and SRP-represented investors contributed to the declassification of 81 S\&P 500 and Fortune 500 companies during 2012 and 2013: 68 declassifications resulting from the passage of management proposals brought pursuant to 2012 or 2013 agreements, seven additional declassifications resulting from 2011 agreements with SRP-represented investors, five companies declassifying following successful precatory proposals at 2012 annual meetings, and one company declassified following a 2013 agreement by amending its bylaws (where company's classified board structures are set out in its bylaws, it may declassify without a shareholder vote).

In this Part VI, we comment on the further movement towards annual elections that we expect to take place during 2014 from the work by the SRP and SRP-represented investors - and in turn on the overall impact that this work is expected to have on the incidence of classified boards among S\&P 500 and Fortune 500 companies by the end of 2014. We expect this work to produce additional board declassification during 2014 for three reasons. First, pursuant to agreements entered into during 2012 and 2013 following the submission of declassification proposals, seven companies are expected to bring management proposal to declassify in 2014. Based on our experience with the passage of agreed-upon management proposals in the course of the 2012 and 2013 proxy seasons, we expect a significant number of additional declassifications to result from these seven agreed-upon management proposals. 
Second, we expect additional declassifications to take place at the 19 S\&P 500 and Fortune 500 companies where precatory proposals were successfully approved by shareholders at 2013 annual meetings. Based on the continued engagement of the SRP and SRP-represented investors, we expect that a significant number of these companies will follow the expressed preference of a large majority of their shareholders and submit management proposals to declassify for a vote during the 2014 proxy season.

Third, the SRP has submitted declassification proposals on behalf of SRP-represented investors to additional S\&P 500 and Fortune 500 companies (which did not receive shareholder proposals from SRPrepresented investors in 2013) for a vote at their 2014 annual meetings. We expect that some of these companies will agree to bring management proposals to move towards annual elections.

Altogether, the 2014 work of the SRP and SRP-represented investors can be expected to produce considerable further movement towards annual elections beyond the declassifications that have already taken place during 2012 and 2013. Overall, we expect that, as a result of work of the SRP and SRPrepresented investors, about 100 S\&P 500 and Fortune 500 companies will move toward annual elections by the end of 2014. Furthermore, we expect that this work will result in board declassifications at more than $60 \%$ of the S\&P 500 companies that had a classified board as of the beginning of 2012, and that it will reduce the incidence of classified boards among S\&P 500 companies to less than $10 \%$.

The declassifications that have been produced by the work of the SRP and SRP-investors, and the additional declassifications that are expected to take place, have produced or will produce governance reforms that are widely supported by institutional investors as corporate governance best practice. The work of the SRP and SRP-represented investors is therefore contributing to moving a substantial number of S\&P 500 companies towards arrangements that are more consistent with the preferences of institutional investors.

\section{Conclusion}

This report provides an overview and analysis of the work that the SRP undertook on behalf of a number of institutional investors during 2012 and 2013, the SRP's first two years of operations. During 2012 and 2013, the SRP worked on behalf of eight SRP-represented investors on board declassification proposals submitted for a vote at the 2012 and/or 2013 annual meetings of 122 S\&P 500 and Fortune 500 companies, and this work has produced substantial results:

In particular, negotiated outcomes involving commitments to board declassification were reached with 100 S\&P 500 and Fortune 500 companies, about three-quarters of the companies receiving proposals in 2012 and/or 2013. In addition, at companies where negotiated outcomes were not reached, 58 
declassification proposals brought by SRP-represented investors received majority support at the 2012 and 2013 annual meetings of 61 S\&P 500 and Fortune 500 companies - all but three proposals that went to a vote - with average support of $81 \%$ of votes cast.

The work by the SRP and SRP-represented investors has already contributed to a substantial reduction in the number of classified boards among S\&P 500 companies. A total of 81 S\&P 500 and Fortune 500 companies have declassified their boards during 2012 and 2013 as a result of this work. These 81 companies, which have an aggregate market capitalization exceeding one trillion dollars (as of 12-31-2013), represent about $65 \%$ of the companies with which engagements took place and about $60 \%$ of the S\&P 500 companies that had classified boards as of the beginning of 2012.

Furthermore, the work of the SRP and SRP-represented investors is expected to produce significant further movement toward board declassification among S\&P 500 and Fortune 500 companies by the end of 2014. We estimate that, by the end of 2014, this work will have contributed to movement towards board declassification by about 100 S\&P 500 and Fortune 500 companies, and by more than 60\% of the S\&P 500 companies that had classified boards as of the beginning of 2012.

Beyond this contribution, the SRP's 2012 and 2013 work facilitated a substantial increase in successful engagement by public pension funds and enhanced their ability to obtain governance changes widely supported by investors. The proposals that the SRP worked on represented over $50 \%$ of the shareholder proposals by public pension funds that received majority support in 2012 and 2013, and over $20 \%$ of all precatory shareholder proposals (by all proponents) that received majority support in 2012 and 2013. 


\section{Appendix A: Outcomes of All 2012 \& 2013 Proposals by Company}

The table below shows the outcome or current status of the 122 S\&P 500 and Fortune 500 companies where SRP-represented investors submitted shareholder proposals for a vote at annual meetings during 2012 and 2013. ${ }^{23}$ The percentages of support shown below are of votes cast.

\begin{tabular}{|c|c|c|c|}
\hline & Company & Proponent & Outcome/Current Status \\
\hline 1. & $\begin{array}{l}\text { Air Products and Chemicals, Inc. } \\
\text { (APD) }\end{array}$ & PRIM & $\begin{array}{l}\text { PRECATORY PROPOSAL PASSED in } \\
2013 \text { ( } 80 \% \text { support); } \\
\text { company announced plan to bring } \\
\text { management declassification proposal to a } \\
\text { vote in } 2014 \text {. }\end{array}$ \\
\hline 2. & Airgas, Inc. (ARG) & LACERA & $\begin{array}{l}\text { PRECATORY PROPOSAL PASSED in } \\
2012 \text { (64\% support); } \\
\text { PRECATORY PROPOSAL PASSED in } \\
2013 \text { ( } 57 \% \text { support). }\end{array}$ \\
\hline 3. & $\begin{array}{l}\text { Akamai Technologies, Inc. } \\
\text { (AKAM) }\end{array}$ & ISBI & $\begin{array}{l}\text { Agreed-upon management } \\
\text { declassification proposal in } 2013 \text { received } \\
\text { majority support but did not pass due to } \\
75 \% \text { supermajority requirement. }\end{array}$ \\
\hline 4. & Alcoa Inc. (AA) & NCDST & $\begin{array}{l}\text { Agreed-upon management } \\
\text { declassification proposal in } 2012 \text { received } \\
\text { majority support but did not pass due to } \\
\text { 80\% supermajority requirement. }\end{array}$ \\
\hline 5. & $\begin{array}{l}\text { Allegheny Technologies } \\
\text { Incorporated (ATI) }\end{array}$ & OPERS & $\begin{array}{l}\text { Agreement reached in 2012; } \\
\text { agreed-upon MANAGEMENT } \\
\text { DECLASSIFICATION PROPOSAL } \\
\text { going to a vote in } 2014 .\end{array}$ \\
\hline 6. & Amphenol Corporation (APH) & NCF & $\begin{array}{l}\text { BOARD DECLASSIFIED after agreed- } \\
\text { upon management declassification } \\
\text { proposal passed in } 2012 \text {. }\end{array}$ \\
\hline
\end{tabular}

${ }^{23}$ In 2013, the precatory proposal submitted to one company was not presented, and the proposal to another was withdrawn due to technical reasons. In addition, a proposal was withdrawn after one company committed to negotiate with a counterparty to amend an agreement that had been in place before the proposal was submitted which requires the company to maintain a staggered board. 


\begin{tabular}{|c|c|c|c|}
\hline 7. & Apache Corporation (APA) & ISBI & $\begin{array}{l}\text { PRECATORY PROPOSAL PASSED in } \\
\text { 2012(89\% support); } \\
\text { company subsequently announced } \\
\text { management declassification proposal } \\
\text { going to a vote in 2013; agreed-upon } \\
\text { management declassification proposal in } \\
2013 \text { received majority support but did } \\
\text { not pass due to 80\% supermajority } \\
\text { requirement. }\end{array}$ \\
\hline 8. & Ashland Inc. (ASH) & PRIM & $\begin{array}{l}\text { PRECATORY PROPOSAL PASSED in } \\
2013 \text { ( } 83 \% \text { support); } \\
\text { company announced plan to bring } \\
\text { management declassification proposal to a } \\
\text { vote in } 2014 \text {. }\end{array}$ \\
\hline 9. & Autoliv, Inc. (ALV) & LACERA & $\begin{array}{l}\text { Agreement reached in 2013; } \\
\text { agreed-upon MANAGEMENT } \\
\text { DECLASSIFICATION PROPOSAL to } \\
\text { go to a vote in } 2014 .\end{array}$ \\
\hline 10. & Baxter International Inc. (BAX) & NCF & $\begin{array}{l}\text { PRECATORY PROPOSAL PASSED in } \\
2012 \text { (99\% support); a precatory proposal } \\
\text { was submitted for the } 2013 \text { annual } \\
\text { meeting and agreement reached; agreed- } \\
\text { upon management declassification } \\
\text { proposal in } 2013 \text { did not pass due to a } \\
\text { supermajority requirement. }\end{array}$ \\
\hline 11. & Bemis Company, Inc. (BMS) & NCDST & $\begin{array}{l}\text { PRECATORY PROPOSAL PASSED in } \\
2012 \text { (75\% support); } \\
\text { BOARD DECLASSIFIED by subsequent } \\
\text { board-adopted bylaw amendment. }\end{array}$ \\
\hline 12. & Best Buy Co, Inc. (BBY) & NCF & $\begin{array}{l}\text { PRECATORY PROPOSAL PASSED in } \\
2012 \text { ( } 97 \% \text { support); } \\
\text { Company subsequently announced } \\
\text { management declassification proposal } \\
\text { going to a vote in 2013; BOARD } \\
\text { DECLASSIFIED after agreed-upon } \\
\text { management declassification proposal } \\
\text { passed in } 2013 \text {. }\end{array}$ \\
\hline 13. & BlackRock, Inc. (BLK) & ISBI & $\begin{array}{l}\text { BOARD DECLASSIFIED after agreed- } \\
\text { upon management declassification } \\
\text { proposal passed in } 2012 \text {. }\end{array}$ \\
\hline 14. & BorgWarner Inc. (BWA) & NCF & $\begin{array}{l}\text { PRECATORY PROPOSAL PASSED in } \\
2013 \text { (99\% support). }\end{array}$ \\
\hline
\end{tabular}




\begin{tabular}{|c|c|c|c|}
\hline 15. & $\begin{array}{l}\text { C.H. Robinson Worldwide, Inc. } \\
\text { (CHRW) }\end{array}$ & NCF & $\begin{array}{l}\text { BOARD DECLASSIFIED after agreed- } \\
\text { upon management declassification } \\
\text { proposal passed in } 2012 \text {. }\end{array}$ \\
\hline 16. & C.R. Bard, Inc. (BCR) & OPERS & $\begin{array}{l}\text { BOARD DECLASSIFIED after agreed- } \\
\text { upon management declassification } \\
\text { proposal passed in } 2012 \text {. }\end{array}$ \\
\hline 17. & $\begin{array}{l}\text { Cabot Oil \& Gas Corporation } \\
\text { (COG) }\end{array}$ & NCDST & $\begin{array}{l}\text { BOARD DECLASSIFIED after agreed- } \\
\text { upon management declassification } \\
\text { proposal passed in } 2012 \text {. }\end{array}$ \\
\hline 18. & $\begin{array}{l}\text { Cameron International Corporation } \\
\text { (CAM) }\end{array}$ & NCDST & $\begin{array}{l}\text { BOARD DECLASSIFIED after agreed- } \\
\text { upon management declassification } \\
\text { proposal passed in } 2012 \text {. }\end{array}$ \\
\hline 19. & CareFusion Corporation (CFN) & $\begin{array}{l}\text { LACERA } \\
\text { (submitted } \\
2012 \text { ) } \\
\text { NCF } \\
\text { (submitted } \\
2013 \text { ) }\end{array}$ & $\begin{array}{l}\text { PRECATORY PROPOSAL PASSED in } \\
2012 \text { (91\% support); } \\
\text { BOARD DECLASSIFIED after agreed- } \\
\text { upon management declassification } \\
\text { proposal passed in } 2013 .\end{array}$ \\
\hline 20. & CarMax, Inc. (KMX) & NCF & $\begin{array}{l}\text { PRECATORY PROPOSAL PASSED in } \\
2012 \text { (87\% support); } \\
\text { a precatory proposal was submitted for } \\
\text { the } 2013 \text { annual meeting and agreement } \\
\text { reached; BOARD DECLASSIFIED after } \\
\text { agreed-upon management declassification } \\
\text { proposal passed in } 2013 \text {. }\end{array}$ \\
\hline 21. & Centene Corporation (CNC) & ISBI & $\begin{array}{l}\text { Agreement reached in 2013; } \\
\text { agreed-upon MANAGEMENT } \\
\text { DECLASSIFICATION PROPOSAL to } \\
\text { go to a vote in } 2014 \text {. }\end{array}$ \\
\hline 22. & CenturyLink, Inc. (CTL) & ISBI & $\begin{array}{l}\text { BOARD DECLASSIFIED after agreed- } \\
\text { upon management declassification } \\
\text { proposal passed in } 2012 \text {. }\end{array}$ \\
\hline 23. & Cerner Corporation (CERN) & ISBI & $\begin{array}{l}\text { PRECATORY PROPOSAL PASSED in } \\
2012 \text { (65\% support); } \\
\text { a precatory proposal was submitted for } \\
\text { the } 2013 \text { annual meeting and agreement } \\
\text { reached; agreed-upon management } \\
\text { declassification proposal in } 2013 \text { received } \\
\text { majority support but did not pass due to } \\
80 \% \text { supermajority requirement. }\end{array}$ \\
\hline
\end{tabular}




\begin{tabular}{|c|c|c|c|}
\hline 24. & CF Industries Holdings, Inc. (CF) & LACERA & $\begin{array}{l}\text { PRECATORY PROPOSAL PASSED in } \\
2012 \text { (93\% support); } \\
\text { company subsequently announced } \\
\text { management declassification proposal } \\
\text { going to a vote in 2013; BOARD } \\
\text { DECLASSIFIED after agreed-upon } \\
\text { management declassification proposal } \\
\text { passed in } 2013 .\end{array}$ \\
\hline 25. & Chipotle Mexican Grill, Inc. (CMG) & ISBI & $\begin{array}{l}\text { PRECATORY PROPOSAL PASSED in } \\
2012 \text { (89\% support); } \\
\text { a precatory proposal was submitted for } \\
\text { the } 2013 \text { annual meeting and agreement } \\
\text { reached; BOARD DECLASSIFIED after } \\
\text { agreed-upon management declassification } \\
\text { proposal passed in } 2013 \text {. }\end{array}$ \\
\hline 26. & CIGNA Corporation (CI) & OPERS & $\begin{array}{l}\text { Agreed-upon management } \\
\text { declassification proposal received } \\
\text { majority support but did not pass due to } \\
80 \% \text { supermajority requirement; } \\
\text { BOARD DECLASSIFIED by subsequent } \\
\text { board-adopted bylaw amendment. }\end{array}$ \\
\hline 27. & Citrix Systems, Inc. (CTXS) & LACERA & $\begin{array}{l}\text { Agreement reached in 2012; } \\
\text { BOARD DECLASSIFIED after agreed- } \\
\text { upon management declassification } \\
\text { proposal passed in } 2013 .\end{array}$ \\
\hline 28. & $\begin{array}{l}\text { Cognizant Technology Solutions } \\
\text { Corporation (CTSH) }\end{array}$ & LACERA & $\begin{array}{l}\text { PRECATORY PROPOSAL PASSED in } \\
2012 \text { (91\% support); } \\
\text { a precatory proposal was submitted for } \\
\text { the } 2013 \text { annual meeting and agreement } \\
\text { reached; BOARD DECLASSIFIED after } \\
\text { agreed-upon management declassification } \\
\text { proposal passed in } 2013 \text {. }\end{array}$ \\
\hline 29. & $\begin{array}{l}\text { Costco Wholesale Corporation } \\
\text { (COST) }\end{array}$ & PRIM & $\begin{array}{l}\text { PRECATORY PROPOSAL PASSED in } \\
2013 \text { ( } 72 \% \text { support); } \\
\text { company announced plan to bring } \\
\text { management declassification proposal to a } \\
\text { vote in } 2014 \text {. }\end{array}$ \\
\hline 30. & Coventry Health Care, Inc. (CVH) & ISBI & $\begin{array}{l}\text { BOARD DECLASSIFIED after agreed- } \\
\text { upon management declassification } \\
\text { proposal passed in } 2012 \text {. }\end{array}$ \\
\hline 31. & $\begin{array}{l}\text { Crown Castle International Corp. } \\
\text { (CCI) }\end{array}$ & SERS & $\begin{array}{l}\text { BOARD DECLASSIFIED after agreed- } \\
\text { upon management declassification } \\
\text { proposal passed in } 2013 \text {. }\end{array}$ \\
\hline
\end{tabular}




\begin{tabular}{|c|c|c|c|}
\hline 32. & $\begin{array}{l}\text { DENTSPLY International Inc. } \\
\text { (XRAY) }\end{array}$ & LACERA & $\begin{array}{l}\text { PRECATORY PROPOSAL PASSED in } \\
2012 \text { ( } 78 \% \text { support); } \\
\text { a precatory proposal was submitted for } \\
\text { the } 2013 \text { annual meeting and agreement } \\
\text { reached; BOARD DECLASSIFIED after } \\
\text { agreed-upon management declassification } \\
\text { proposal passed in } 2013 \text {. }\end{array}$ \\
\hline 33. & DeVRY, Inc. (DV) & PRIM & $\begin{array}{l}\text { BOARD DECLASSIFIED after agreed- } \\
\text { upon management declassification } \\
\text { proposal passed in } 2012 \text {. }\end{array}$ \\
\hline 34. & $\begin{array}{l}\text { Edwards Lifesciences Corporation } \\
(\mathrm{EW})\end{array}$ & ISBI & $\begin{array}{l}\text { PRECATORY PROPOSAL PASSED in } \\
2012 \text { (99\% support); } \\
\text { a precatory proposal was submitted for } \\
\text { the } 2013 \text { annual meeting and agreement } \\
\text { reached; BOARD DECLASSIFIED after } \\
\text { agreed-upon management declassification } \\
\text { proposal passed in } 2013 \text {. }\end{array}$ \\
\hline 35. & Eli Lilly and Company (LLY) & NCF & $\begin{array}{l}\text { Agreed-upon management } \\
\text { declassification proposal in } 2012 \text { received } \\
\text { majority support but did not pass due to } \\
\text { 80\% supermajority requirement. }\end{array}$ \\
\hline 36. & EQT Corporation (EQT) & OPERS & $\begin{array}{l}\text { PRECATORY PROPOSAL PASSED in } \\
2012 \text { ( } 81 \% \text { support); } \\
\text { a precatory proposal was submitted for } \\
\text { the } 2013 \text { annual meeting and agreement } \\
\text { reached; BOARD DECLASSIFIED after } \\
\text { agreed-upon management declassification } \\
\text { proposal passed in } 2013 \text {. }\end{array}$ \\
\hline 37. & F5 Networks, Inc. (FFIV) & ISBI & $\begin{array}{l}\text { PRECATORY PROPOSAL PASSED in } \\
2012 \text { (77\% support); } \\
\text { company subsequently announced } \\
\text { management declassification proposal } \\
\text { going to a vote in 2013; BOARD } \\
\text { DECLASSIFIED after agreed-upon } \\
\text { management declassification proposal } \\
\text { passed in } 2013 .\end{array}$ \\
\hline 38. & $\begin{array}{l}\text { Fidelity National Information } \\
\text { Services, Inc. (FIS) }\end{array}$ & ISBI & $\begin{array}{l}\text { BOARD DECLASSIFIED after agreed- } \\
\text { upon management declassification } \\
\text { proposal passed in } 2012 \text {. }\end{array}$ \\
\hline
\end{tabular}




\begin{tabular}{|c|c|c|c|}
\hline 39. & FLIR Systems, Inc. (FLIR) & NCF & $\begin{array}{l}\text { PRECATORY PROPOSAL PASSED in } \\
2012 \text { (82\% support); } \\
\text { a precatory proposal was submitted for } \\
\text { the } 2013 \text { annual meeting and agreement } \\
\text { reached; BOARD DECLASSIFIED after } \\
\text { agreed-upon management declassification } \\
\text { proposal passed in } 2013 \text {. }\end{array}$ \\
\hline 40. & Flowserve Corporation (FLS) & NCDST & $\begin{array}{l}\text { BOARD DECLASSIFIED after agreed- } \\
\text { upon management declassification } \\
\text { proposal passed in } 2012 \text {. }\end{array}$ \\
\hline 41. & FMC Corporation (FMC) & NCF & $\begin{array}{l}\text { PRECATORY PROPOSAL PASSED in } \\
2012 \text { (83\% support); } \\
\text { a precatory proposal was submitted for } \\
\text { the } 2013 \text { annual meeting and agreement } \\
\text { reached; BOARD DECLASSIFIED after } \\
\text { agreed-upon management declassification } \\
\text { proposal passed in } 2013 \text {. }\end{array}$ \\
\hline 42. & FMC Technologies, Inc. (FTI) & NCDST & $\begin{array}{l}\text { BOARD DECLASSIFIED after agreed- } \\
\text { upon management declassification } \\
\text { proposal passed in } 2012 \text {. }\end{array}$ \\
\hline 43. & Foot Locker, Inc. (FL) & NCDST & $\begin{array}{l}\text { PRECATORY PROPOSAL PASSED in } \\
2013 \text { ( } 91 \% \text { support). }\end{array}$ \\
\hline 44. & GameStop Corp. (GME) & NCF & $\begin{array}{l}\text { Agreement reached in 2012; } \\
\text { BOARD DECLASSIFIED after agreed- } \\
\text { upon management declassification } \\
\text { proposal passed in } 2013 .\end{array}$ \\
\hline 45. & Helmerich \& Payne (HP) & NCDST & $\begin{array}{l}\text { BOARD DECLASSIFIED after agreed- } \\
\text { upon management declassification } \\
\text { proposal passed in } 2012 \text {. }\end{array}$ \\
\hline 46. & Hess Corporation (HES) & NCDST & $\begin{array}{l}\text { PRECATORY PROPOSAL PASSED in } \\
2012 \text { (78\% support); } \\
\text { a precatory proposal was submitted for } \\
\text { the } 2013 \text { annual meeting and agreement } \\
\text { reached; BOARD DECLASSIFIED after } \\
\text { agreed-upon management declassification } \\
\text { proposal passed in } 2013 \text {. }\end{array}$ \\
\hline 47. & Hudson City Bancorp, Inc. (HCBK) & NCF & $\begin{array}{l}\text { BOARD DECLASSIFIED after agreed- } \\
\text { upon management declassification } \\
\text { proposal passed in } 2012 \text {. }\end{array}$ \\
\hline 48. & Huntsman Corporation (HUN) & SBA & $\begin{array}{l}\text { PRECATORY PROPOSAL PASSED in } \\
2013 \text { (59\% support). }\end{array}$ \\
\hline 49. & Intuitive Surgical, Inc. (ISRG) & NCDST & $\begin{array}{l}\text { BOARD DECLASSIFIED after agreed- } \\
\text { upon management declassification } \\
\text { proposal passed in } 2012 \text {. }\end{array}$ \\
\hline
\end{tabular}




\begin{tabular}{|c|c|c|c|}
\hline 50. & JDS Uniphase Corporation (JDSU) & PRIM & $\begin{array}{l}\text { BOARD DECLASSIFIED after agreed- } \\
\text { upon management declassification } \\
\text { proposal passed in } 2012 \text {. }\end{array}$ \\
\hline 51. & Jacobs Engineering Group Inc. (JEC) & PRIM & $\begin{array}{l}\text { PRECATORY PROPOSAL PASSED in } \\
2013 \text { (82\% support); } \\
\text { company announced plan to bring } \\
\text { management declassification proposal to a } \\
\text { vote in } 2014 \text {. }\end{array}$ \\
\hline 52. & Janus Capital Group Inc. (JNS) & NCDST & $\begin{array}{l}\text { BOARD DECLASSIFIED after agreed- } \\
\text { upon management declassification } \\
\text { proposal passed in } 2012 \text {. }\end{array}$ \\
\hline 53. & Jarden Corporation (JAH) & NCDST & $\begin{array}{l}\text { PRECATORY PROPOSAL PASSED in } \\
2013 \text { (88\% support). }\end{array}$ \\
\hline 54. & Johnson Controls, Inc. (JCI) & PRIM & $\begin{array}{l}\text { BOARD DECLASSIFIED after agreed- } \\
\text { upon management declassification } \\
\text { proposal passed in } 2013 \text {. }\end{array}$ \\
\hline 55. & Juniper Networks, Inc. (JNPR) & ISBI & $\begin{array}{l}\text { BOARD DECLASSIFIED after agreed- } \\
\text { upon management declassification } \\
\text { proposal passed in } 2012 \text {. }\end{array}$ \\
\hline 56. & Kellogg Company (K) & NCDST & $\begin{array}{l}\text { Precatory proposal did not pass; } \\
\text { a precatory proposal was submitted for } \\
\text { the } 2013 \text { annual meeting and PASSED } \\
\text { (52\% support). }\end{array}$ \\
\hline 57. & KLA-Tencor Corporation (KLAC) & PRIM & $\begin{array}{l}\text { BOARD DECLASSIFIED after agreed- } \\
\text { upon management declassification } \\
\text { proposal passed in } 2012 \text {. }\end{array}$ \\
\hline 58. & $\begin{array}{l}\text { L-3 Communications Holdings, Inc. } \\
\text { (LLL) }\end{array}$ & NCDST & $\begin{array}{l}\text { BOARD DECLASSIFIED after agreed- } \\
\text { upon management declassification } \\
\text { proposal passed in } 2013 \text {. }\end{array}$ \\
\hline 59. & Lexmark International, Inc. (LXK) & NCDST & $\begin{array}{l}\text { PRECATORY PROPOSAL PASSED in } \\
2012 \text { (93\% support); } \\
\text { a precatory proposal was submitted for } \\
\text { the } 2013 \text { annual meeting and agreement } \\
\text { reached; BOARD DECLASSIFIED after } \\
\text { agreed-upon management declassification } \\
\text { proposal passed in } 2013 \text {. }\end{array}$ \\
\hline 60. & Limited Brands, Inc. (LTD) & ISBI & $\begin{array}{l}\text { PRECATORY PROPOSAL PASSED in } \\
2012 \text { (65\% support); } \\
\text { a precatory proposal was submitted for } \\
\text { the } 2013 \text { annual meeting and agreement } \\
\text { reached; agreed-upon management } \\
\text { declassification proposal received } \\
\text { majority support but did not pass due to } \\
75 \% \text { supermajority requirement. }\end{array}$ \\
\hline
\end{tabular}




\begin{tabular}{|c|c|c|c|}
\hline 61. & Lincoln National Corporation (LNC) & SERS & $\begin{array}{l}\text { BOARD DECLASSIFIED by board- } \\
\text { adopted bylaw amendment. }\end{array}$ \\
\hline 62. & Lorillard, Inc. (LO) & ISBI & $\begin{array}{l}\text { PRECATORY PROPOSAL PASSED in } \\
2012 \text { (96\% support); } \\
\text { a precatory proposal was submitted for } \\
\text { the } 2013 \text { annual meeting agreement } \\
\text { reached; BOARD DECLASSIFIED after } \\
\text { agreed-upon management declassification } \\
\text { proposal passed in } 2013 \text {. }\end{array}$ \\
\hline 63. & Manpower Inc. (MAN) & SBA & $\begin{array}{l}\text { BOARD DECLASSIFIED after agreed- } \\
\text { upon management declassification } \\
\text { proposal passed in } 2013 \text {. }\end{array}$ \\
\hline 64. & $\begin{array}{l}\text { Marathon Petroleum Corporation } \\
\text { (MPC) }\end{array}$ & NCF & $\begin{array}{l}\text { Agreed-upon management } \\
\text { declassification proposal in } 2013 \text { received } \\
\text { majority support but did not pass due to } \\
\text { 80\% supermajority requirement. }\end{array}$ \\
\hline 65. & Masco Corporation (MAS) & ISBI & $\begin{array}{l}\text { PRECATORY PROPOSAL PASSED in } \\
2012 \text { (85\% support); } \\
\text { a precatory proposal was submitted for } \\
\text { the } 2013 \text { annual meeting and agreement } \\
\text { reached; agreed-upon management } \\
\text { declassification proposal received } \\
\text { majority support but did not pass due to } \\
80 \% \text { supermajority requirement. }\end{array}$ \\
\hline 66. & McDonald's Corporation (MCD) & LACERA & $\begin{array}{l}\text { BOARD DECLASSIFIED after agreed- } \\
\text { upon management declassification } \\
\text { proposal passed in } 2012 \text {. }\end{array}$ \\
\hline 67. & $\begin{array}{l}\text { MEMC Electronic Materials, Inc. } \\
\text { (WFR) }\end{array}$ & NCDST & $\begin{array}{l}\text { PRECATORY PROPOSAL PASSED in } \\
2012 \text { (96\% support); } \\
\text { company subsequently announced } \\
\text { management declassification proposal } \\
\text { going to a vote in 2013; BOARD } \\
\text { DECLASSIFIED after the company’s } \\
\text { announced management declassification } \\
\text { proposal passed in } 2013 \text {. }\end{array}$ \\
\hline 68. & $\begin{array}{l}\text { MetroPCS Communications, Inc. } \\
\text { (PCS) }\end{array}$ & LACERA & $\begin{array}{l}\text { Agreement reached in 2012; } \\
\text { BOARD DECLASSIFIED after agreed- } \\
\text { upon management declassification } \\
\text { proposal passed in } 2013 .\end{array}$ \\
\hline 69. & Monsanto Company (MON) & PRIM & $\begin{array}{l}\text { BOARD DECLASSIFIED after agreed- } \\
\text { upon management declassification } \\
\text { proposal passed in } 2013 \text {. }\end{array}$ \\
\hline
\end{tabular}




\begin{tabular}{|c|c|c|c|}
\hline 70. & Moody's Corporation (MCO) & NCF & $\begin{array}{l}\text { PRECATORY PROPOSAL PASSED in } \\
2012 \text { ( } 77 \% \text { support); } \\
\text { a precatory proposal was submitted for } \\
\text { the } 2013 \text { annual meeting and agreement } \\
\text { reached; BOARD DECLASSIFIED after } \\
\text { agreed-upon management declassification } \\
\text { proposal passed in } 2013 \text {. }\end{array}$ \\
\hline 71. & NCR Corporation (NCR) & SBA & $\begin{array}{l}\text { PRECATORY PROPOSAL PASSED in } \\
2013 \text { (80\% support). }\end{array}$ \\
\hline 72. & Netflix, Inc. (NFLX) & $\begin{array}{l}\text { LACERA } \\
\text { (submitted } \\
\text { 2012) } \\
\text { SBA } \\
\text { (submitted } \\
\text { 2013) }\end{array}$ & $\begin{array}{l}\text { PRECATORY PROPOSAL PASSED in } \\
2012 \text { (75\% support); } \\
\text { a precatory proposal was submitted for } \\
\text { the } 2013 \text { annual meeting and PASSED } \\
\text { (88\% support). }\end{array}$ \\
\hline 73. & Newell Rubbermaid Inc. (NWL) & ISBI & $\begin{array}{l}\text { BOARD DECLASSIFIED after agreed- } \\
\text { upon management declassification } \\
\text { proposal passed in } 2012 \text {. }\end{array}$ \\
\hline 74. & NII Holdings, Inc. (NIHD) & SBA & $\begin{array}{l}\text { BOARD DECLASSIFIED after agreed- } \\
\text { upon management declassification } \\
\text { proposal passed in } 2013 \text {. }\end{array}$ \\
\hline 75. & NRG Energy, Inc. (NRG) & NCDST & $\begin{array}{l}\text { BOARD DECLASSIFIED after agreed- } \\
\text { upon management declassification } \\
\text { proposal passed in } 2012 \text {. }\end{array}$ \\
\hline 76. & O'Reilly Automotive, Inc. (ORLY) & NCF & $\begin{array}{l}\text { Agreement reached in 2012; } \\
\text { BOARD DECLASSIFIED after agreed- } \\
\text { upon management declassification } \\
\text { proposal passed in } 2013 .\end{array}$ \\
\hline 77. & Owens Corning (OC) & ISBI & $\begin{array}{l}\text { Agreement reached in 2013; agreed-upon } \\
\text { MANAGEMENT DECLASSIFICATION } \\
\text { PROPOSAL to go to a vote in } 2014 \text {. }\end{array}$ \\
\hline 78. & Owens-Illinois, Inc. (OI) & ISBI & $\begin{array}{l}\text { BOARD DECLASSIFIED after agreed- } \\
\text { upon management declassification } \\
\text { proposal passed in } 2012 \text {. }\end{array}$ \\
\hline 79. & PACCAR Inc. (PCAR) & NCDST & $\begin{array}{l}\text { Precatory proposal did not pass in } 2012 \text {; } \\
\text { a precatory proposal was submitted for } \\
\text { the } 2013 \text { annual meeting and did not pass. }\end{array}$ \\
\hline 80. & Patterson Companies, Inc. (PDCO) & PRIM & $\begin{array}{l}\text { BOARD DECLASSIFIED after agreed- } \\
\text { upon management declassification } \\
\text { proposal passed in } 2012 \text {. }\end{array}$ \\
\hline
\end{tabular}




\begin{tabular}{|c|c|c|c|}
\hline 81. & $\begin{array}{l}\text { People's United Financial, Inc. } \\
\text { (PBCT) }\end{array}$ & NCDST & $\begin{array}{l}\text { PRECATORY PROPOSAL PASSED in } \\
2012 \text { (91\% support); } \\
\text { a precatory proposal was submitted for } \\
\text { the } 2013 \text { annual meeting and agreement } \\
\text { reached; BOARD DECLASSIFIED after } \\
\text { agreed-upon management declassification } \\
\text { proposal passed in } 2013 \text {. }\end{array}$ \\
\hline 82. & Perrigo Company (PRGO) & LACERA & $\begin{array}{l}\text { Precatory proposal was submitted for } \\
\text { 2013; after the company agreed to move } \\
\text { toward declassification the company } \\
\text { declassified as part of a merger. }\end{array}$ \\
\hline 83. & $\begin{array}{l}\text { Pioneer Natural Resources Company } \\
\text { (PXD) }\end{array}$ & LACERA & $\begin{array}{l}\text { BOARD DECLASSIFIED after agreed- } \\
\text { upon management declassification } \\
\text { proposal passed in } 2012 \text {. }\end{array}$ \\
\hline 84. & PPG Industries, Inc. (PPG) & NCDST & $\begin{array}{l}\text { Agreed-upon management } \\
\text { declassification proposal in } 2012 \text { received } \\
\text { majority support but did not pass due to } \\
80 \% \text { supermajority requirement; } \\
\text { a precatory proposal was submitted for } \\
\text { the } 2013 \text { annual meeting and agreement } \\
\text { reached; agreed-upon management } \\
\text { declassification proposal received } \\
\text { majority support but did not pass due to } \\
80 \% \text { supermajority requirement. }\end{array}$ \\
\hline 85. & $\begin{array}{l}\text { Principal Financial Group, Inc. } \\
\text { (PFG) }\end{array}$ & ISBI & $\begin{array}{l}\text { Agreement reached in } 2012 \text {; } \\
\text { agreed-upon management declassification } \\
\text { proposal received majority support but } \\
\text { did not pass due to } 75 \% \text { supermajority } \\
\text { requirement. }\end{array}$ \\
\hline 86. & QEP Resources, Inc. (QEP) & ISBI & $\begin{array}{l}\text { PRECATORY PROPOSAL PASSED in } \\
2012 \text { ( } 88 \% \text { support); } \\
\text { a precatory proposal was submitted for } \\
\text { the } 2013 \text { annual meeting and agreement } \\
\text { reached; agreed-upon management } \\
\text { declassification proposal received } \\
\text { majority support but did not pass due to } \\
\text { 80\% supermajority requirement. }\end{array}$ \\
\hline
\end{tabular}




\begin{tabular}{|c|c|c|c|}
\hline 87. & $\begin{array}{l}\text { Quest Diagnostics Incorporated } \\
\text { (DGX) }\end{array}$ & ISBI & $\begin{array}{l}\text { PRECATORY PROPOSAL PASSED in } \\
2012 \text { (94\% support); } \\
\text { company subsequently announced } \\
\text { management declassification proposal } \\
\text { going to a vote in 2013; BOARD } \\
\text { DECLASSIFIED after the company’s } \\
\text { announced management declassification } \\
\text { proposal passed in } 2013 \text {. }\end{array}$ \\
\hline 88. & Red Hat, Inc. (RHT) & LACERA & $\begin{array}{l}\text { PRECATORY PROPOSAL PASSED in } \\
2012 \text { (95\% support); } \\
\text { a precatory proposal was submitted for } \\
\text { the } 2013 \text { annual meeting and agreement } \\
\text { reached; BOARD DECLASSIFIED after } \\
\text { agreed-upon management declassification } \\
\text { proposal passed in } 2013 \text {. }\end{array}$ \\
\hline 89. & $\begin{array}{l}\text { Reinsurance Group of America, } \\
\text { Incorporated (RGA) }\end{array}$ & SERS & $\begin{array}{l}\text { Agreed-upon management } \\
\text { declassification proposal in } 2013 \text { received } \\
\text { majority support but did not pass due to } \\
\text { 85\% supermajority requirement. }\end{array}$ \\
\hline 90. & Rockwell Collins, Inc. (COL) & PRIM & $\begin{array}{l}\text { PRECATORY PROPOSAL PASSED in } \\
2013 \text { (83\% support); } \\
\text { company announced plan to bring } \\
\text { management declassification proposal to a } \\
\text { vote in } 2014 \text {. }\end{array}$ \\
\hline 91. & Roper Industries, Inc. (ROP) & LACERA & $\begin{array}{l}\text { Agreement reached in 2012; } \\
\text { agreed-upon MANAGEMENT } \\
\text { DECLASSIFICATION PROPOSAL } \\
\text { going to a vote in } 2013 .\end{array}$ \\
\hline 92. & Rowan Companies, Inc. (RDC) & NCDST & $\begin{array}{l}\text { BOARD DECLASSIFIED after agreed- } \\
\text { upon management declassification } \\
\text { proposal passed in } 2012 \text {. }\end{array}$ \\
\hline 93. & Ryder System, Inc. (R) & NCDST & $\begin{array}{l}\text { PRECATORY PROPOSAL PASSED in } \\
2012 \text { (88\% support); } \\
\text { a precatory proposal was submitted for } \\
\text { the } 2013 \text { annual meeting and agreement } \\
\text { reached; BOARD DECLASSIFIED after } \\
\text { agreed-upon management declassification } \\
\text { proposal passed in } 2013 \text {. }\end{array}$ \\
\hline
\end{tabular}




\begin{tabular}{|c|c|c|c|}
\hline & salesforce.com, inc. (CRM) & NCF & $\begin{array}{l}\text { PRECATORY PROPOSAL PASSED in } \\
2012 \text { (81\% support); } \\
\text { a precatory proposal was submitted for } \\
\text { the } 2013 \text { annual meeting and agreement } \\
\text { reached; BOARD DECLASSIFIED after } \\
\text { agreed-upon management declassification } \\
\text { proposal passed in } 2013 \text {. }\end{array}$ \\
\hline 95. & SCANA Corporation (SCG) & $\begin{array}{l}\text { NCDST } \\
\text { (submitted } \\
2012 \text { ) } \\
\text { SERS } \\
\text { (submitted } \\
2013 \text { ) }\end{array}$ & $\begin{array}{l}\text { PRECATORY PROPOSAL PASSED in } \\
2012 \text { (60\% support); } \\
\text { a precatory proposal was submitted for } \\
\text { the } 2013 \text { annual meeting and PASSED } \\
\text { ( } 70 \% \text { support). }\end{array}$ \\
\hline 96. & Snap-On Incorporated (SNA) & NCDST & $\begin{array}{l}\text { PRECATORY PROPOSAL PASSED in } \\
2012 \text { ( } 85 \% \text { support); } \\
\text { a precatory proposal was submitted for } \\
\text { the } 2013 \text { annual meeting and agreement } \\
\text { reached; BOARD DECLASSIFIED after } \\
\text { agreed-upon management declassification } \\
\text { proposal passed in } 2013 \text {. }\end{array}$ \\
\hline 97. & SPX Corporation (SPW) & SBA & $\begin{array}{l}\text { Agreed-upon management } \\
\text { declassification proposal in } 2013 \text { received } \\
\text { majority support but did not pass due to } \\
\text { 80\% supermajority requirement. }\end{array}$ \\
\hline 98. & St. Jude Medical, Inc. (STJ) & ISBI & $\begin{array}{l}\text { Agreed-upon management } \\
\text { declassification proposal in } 2012 \text { received } \\
\text { majority support but did not pass due to } \\
80 \% \text { supermajority requirement; } \\
\text { a precatory proposal was submitted for } \\
\text { the } 2013 \text { annual meeting and agreement } \\
\text { reached; agreed-upon management } \\
\text { declassification proposal received } \\
\text { majority support but did not pass due to } \\
80 \% \text { supermajority requirement. }\end{array}$ \\
\hline 99. & $\begin{array}{l}\text { Stanley Black \& Decker, Inc. } \\
\text { (SWK) }\end{array}$ & NCDST & $\begin{array}{l}\text { BOARD DECLASSIFIED after agreed- } \\
\text { upon management declassification } \\
\text { proposal passed in } 2012 \text {. }\end{array}$ \\
\hline 100. & Tech Data Corporation (TECD) & SERS & $\begin{array}{l}\text { Agreement reached in 2013; } \\
\text { agreed-upon MANAGEMENT } \\
\text { DECLASSIFICATION PROPOSAL to } \\
\text { go to a vote at the coming annual meeting } \\
\text { (which has been postponed from 2013). }\end{array}$ \\
\hline
\end{tabular}




\begin{tabular}{|c|c|c|c|}
\hline 101. & TECO Energy, Inc. (TE) & NCF & $\begin{array}{l}\text { BOARD DECLASSIFIED after agreed- } \\
\text { upon management declassification } \\
\text { proposal passed in } 2012 \text {. }\end{array}$ \\
\hline 102. & Tellabs, Inc. (TLAB) & OPERS & $\begin{array}{l}\text { Agreement reached in 2012; } \\
\text { agreed-upon management declassification } \\
\text { proposal in } 2013 \text { received majority } \\
\text { support but did not pass due to } 75 \% \\
\text { supermajority requirement. }\end{array}$ \\
\hline 103. & Teradata Corporation (TDC) & NCDST & $\begin{array}{l}\text { Agreed-upon management } \\
\text { declassification proposal in } 2012 \text { received } \\
\text { majority support but did not pass due to } \\
\text { 80\% supermajority requirement; } \\
\text { PRECATORY PROPOSAL PASSED in } \\
2013 \text { (99\% support). }\end{array}$ \\
\hline 104. & The J. M. Smucker Company (SJM) & LACERA & $\begin{array}{l}\text { PRECATORY PROPOSAL PASSED in } \\
2012 \text { ( } 77 \% \text { support); } \\
\text { a precatory proposal was submitted for } \\
\text { the } 2013 \text { annual meeting and agreement } \\
\text { reached; BOARD DECLASSIFIED after } \\
\text { agreed-upon management declassification } \\
\text { proposal passed in } 2013 \text {. }\end{array}$ \\
\hline 105. & The Mosaic Company (MOS) & OPERS & $\begin{array}{l}\text { Agreement reached in 2013; } \\
\text { agreed-upon MANAGEMENT } \\
\text { DECLASSIFICATION PROPOSAL to } \\
\text { go to a vote in } 2014 .\end{array}$ \\
\hline 106. & The Progressive Corporation (PGR) & ISBI & $\begin{array}{l}\text { BOARD DECLASSIFIED after agreed- } \\
\text { upon management declassification } \\
\text { proposal passed in } 2012 \text {. }\end{array}$ \\
\hline 107. & The Western Union Company (WU) & NCF & $\begin{array}{l}\text { BOARD DECLASSIFIED after agreed- } \\
\text { upon management declassification } \\
\text { proposal passed in } 2012 \text {. }\end{array}$ \\
\hline 108. & United Natural Foods, Inc. (UNFI) & ISBI & $\begin{array}{l}\text { BOARD DECLASSIFIED after agreed- } \\
\text { upon management declassification } \\
\text { proposal passed in } 2013 \text {. }\end{array}$ \\
\hline 109. & United States Steel Corporation (X) & NCDST & $\begin{array}{l}\text { PRECATORY PROPOSAL PASSED in } \\
2012 \text { (82\% support); } \\
\text { PRECATORY PROPOSAL PASSED in } \\
2013 \text { (81\% support). }\end{array}$ \\
\hline 110. & Unum Group (UNM) & LACERA & $\begin{array}{l}\text { Agreement reached in 2012; } \\
\text { BOARD DECLASSIFIED after agreed- } \\
\text { upon management declassification } \\
\text { proposal passed in } 2013 \text {. }\end{array}$ \\
\hline
\end{tabular}




\begin{tabular}{|c|c|c|c|}
\hline 111. & Urban Outfitters, Inc. (URBN) & ISBI & $\begin{array}{l}\text { PRECATORY PROPOSAL PASSED in } \\
2012 \text { (60\% support); } \\
\text { BOARD DECLASSIFIED by subsequent } \\
\text { board-adopted bylaw amendment. }\end{array}$ \\
\hline 112. & US Airways Group, Inc. (LCC) & ISBI & $\begin{array}{l}\text { Agreement reached in 2013; } \\
\text { agreed-upon MANAGEMENT } \\
\text { DECLASSIFICATION PROPOSAL to } \\
\text { go to a vote in } 2014 \text {. }\end{array}$ \\
\hline 113. & V. F. Corporation (VFC) & NCF & $\begin{array}{l}\text { PRECATORY PROPOSAL PASSED in } \\
2012 \text { (63\% support); } \\
\text { BOARD DECLASSIFIED by subsequent } \\
\text { board-adopted bylaw amendment. }\end{array}$ \\
\hline 114. & Varian Medical Systems, Inc. (VAR) & PRIM & $\begin{array}{l}\text { PRECATORY PROPOSAL PASSED in } \\
2013 \text { (75\% support); } \\
\text { company announced plan to bring } \\
\text { management declassification proposal to a } \\
\text { vote in } 2014 \text {. }\end{array}$ \\
\hline 115. & Vornado Realty Trust (VNO) & ISBI & $\begin{array}{l}\text { PRECATORY PROPOSAL PASSED in } \\
2012 \text { (86\% support); } \\
\text { PRECATORY PROPOSAL PASSED in } \\
2013 \text { (84\% support). }\end{array}$ \\
\hline 116. & Vulcan Materials Company (VMC) & ISBI & $\begin{array}{l}\text { PRECATORY PROPOSAL PASSED in } \\
2012 \text { ( } 73 \% \text { support); } \\
\text { a precatory proposal was submitted for } \\
\text { the } 2013 \text { annual meeting and agreement } \\
\text { reached; agreed-upon management } \\
\text { declassification proposal received } \\
\text { majority support but did not pass due to } \\
\text { 80\% supermajority requirement. }\end{array}$ \\
\hline 117. & WESCO International, Inc. (WCC) & LACERA & $\begin{array}{l}\text { PRECATORY PROPOSAL PASSED in } \\
2013 \text { (88\% support). }\end{array}$ \\
\hline 118. & $\begin{array}{l}\text { Wyndham Worldwide Corporation } \\
\text { (WYN) }\end{array}$ & NCF & $\begin{array}{l}\text { BOARD DECLASSIFIED after agreed- } \\
\text { upon management declassification } \\
\text { proposal passed in } 2012 \text {. }\end{array}$ \\
\hline 119. & Xylem Inc. (XYL) & NCF & $\begin{array}{l}\text { BOARD DECLASSIFIED after agreed- } \\
\text { upon management declassification } \\
\text { proposal passed in } 2013 \text {. }\end{array}$ \\
\hline
\end{tabular}




\section{Appendix B: Outcomes of All 2012 \& 2013 Proposals by Proponent}

For each of the SRP-represented investors with which the SRP work in connection with shareholder proposals submitted to 2012 and 2013 annual meetings, the tables below provide the outcome or current status of the engagement. The percentages of support shown below are of votes cast.

\section{A. Outcomes of all 2012 \& 2013 Proposals by ISBI}

\begin{tabular}{|c|c|c|c|}
\hline & Company & Proponent & Outcome/Current Status \\
\hline 1. & Akamai Technologies, Inc. (AKAM) & ISBI & $\begin{array}{l}\text { Agreed-upon management } \\
\text { declassification proposal in } 2013 \text { received } \\
\text { majority support but did not pass due to } \\
75 \% \text { supermajority requirement. }\end{array}$ \\
\hline 2. & Apache Corporation (APA) & ISBI & $\begin{array}{l}\text { PRECATORY PROPOSAL PASSED } \\
\text { (89\% support); } \\
\text { company subsequently announced } \\
\text { management declassification proposal } \\
\text { going to a vote in 2013; agreed-upon } \\
\text { management declassification proposal in } \\
2013 \text { received majority support but did } \\
\text { not pass due to 80\% supermajority } \\
\text { requirement. }\end{array}$ \\
\hline 3. & BlackRock, Inc. (BLK) & ISBI & $\begin{array}{l}\text { BOARD DECLASSIFIED after agreed- } \\
\text { upon management declassification } \\
\text { proposal passed in } 2012 \text {. }\end{array}$ \\
\hline & Centene Corporation (CNC) & ISBI & $\begin{array}{l}\text { Agreement reached in 2013; } \\
\text { agreed-upon MANAGEMENT } \\
\text { DECLASSIFICATION PROPOSAL to } \\
\text { go to a vote in } 2014 \text {. }\end{array}$ \\
\hline 5. & CenturyLink, Inc. (CTL) & ISBI & $\begin{array}{l}\text { BOARD DECLASSIFIED after agreed- } \\
\text { upon management declassification } \\
\text { proposal passed in } 2012 \text {. }\end{array}$ \\
\hline 6. & Cerner Corporation (CERN) & ISBI & $\begin{array}{l}\text { PRECATORY PROPOSAL PASSED in } \\
2012 \text { (65\% support); } \\
\text { a precatory proposal was submitted for } \\
\text { the } 2013 \text { annual meeting and agreement } \\
\text { reached; agreed-upon management } \\
\text { declassification proposal in } 2013 \text { received } \\
\text { majority support but did not pass due to } \\
80 \% \text { supermajority requirement. }\end{array}$ \\
\hline
\end{tabular}




\begin{tabular}{|c|c|c|c|}
\hline 7. & Chipotle Mexican Grill, Inc. (CMG) & ISBI & $\begin{array}{l}\text { PRECATORY PROPOSAL PASSED in } \\
2012 \text { (89\% support); } \\
\text { a precatory proposal was submitted for } \\
\text { the } 2013 \text { annual meeting and agreement } \\
\text { reached; BOARD DECLASSIFIED after } \\
\text { agreed-upon management declassification } \\
\text { proposal passed in } 2013 \text {. }\end{array}$ \\
\hline 8. & Coventry Health Care, Inc. (CVH) & ISBI & $\begin{array}{l}\text { BOARD DECLASSIFIED after agreed- } \\
\text { upon management declassification } \\
\text { proposal passed in } 2012 \text {. }\end{array}$ \\
\hline 9. & Edwards Lifesciences Corporation (EW) & ISBI & $\begin{array}{l}\text { PRECATORY PROPOSAL PASSED in } \\
2012 \text { (99\% support); } \\
\text { a precatory proposal was submitted for } \\
\text { the } 2013 \text { annual meeting and agreement } \\
\text { reached; BOARD DECLASSIFIED after } \\
\text { agreed-upon management declassification } \\
\text { proposal passed in } 2013 \text {. }\end{array}$ \\
\hline 10. & F5 Networks, Inc. (FFIV) & ISBI & $\begin{array}{l}\text { PRECATORY PROPOSAL PASSED in } \\
2012 \text { ( } 77 \% \text { support); } \\
\text { company subsequently announced } \\
\text { management declassification proposal } \\
\text { going to a vote in 2013; BOARD } \\
\text { DECLASSIFIED after agreed-upon } \\
\text { management declassification proposal } \\
\text { passed in } 2013 .\end{array}$ \\
\hline 11. & $\begin{array}{l}\text { Fidelity National Information Services, } \\
\text { Inc. (FIS) }\end{array}$ & ISBI & $\begin{array}{l}\text { BOARD DECLASSIFIED after agreed- } \\
\text { upon management declassification } \\
\text { proposal passed in } 2012 \text {. }\end{array}$ \\
\hline & Juniper Networks, Inc. (JNPR) & ISBI & $\begin{array}{l}\text { BOARD DECLASSIFIED after agreed- } \\
\text { upon management declassification } \\
\text { proposal passed in } 2012 \text {. }\end{array}$ \\
\hline & Limited Brands, Inc. (LTD) & ISBI & $\begin{array}{l}\text { PRECATORY PROPOSAL PASSED in } \\
2012 \text { (65\% support); } \\
\text { a precatory proposal was submitted for } \\
\text { the } 2013 \text { annual meeting and agreement } \\
\text { reached; agreed-upon management } \\
\text { declassification proposal received } \\
\text { majority support but did not pass due to } \\
75 \% \text { supermajority requirement. }\end{array}$ \\
\hline
\end{tabular}




\begin{tabular}{|c|c|c|}
\hline 14. Lorillard, Inc. (LO) & ISBI & $\begin{array}{l}\text { PRECATORY PROPOSAL PASSED in } \\
2012 \text { (96\% support); } \\
\text { a precatory proposal was submitted for } \\
\text { the } 2013 \text { annual meeting agreement } \\
\text { reached; BOARD DECLASSIFIED after } \\
\text { agreed-upon management declassification } \\
\text { proposal passed in } 2013 \text {. }\end{array}$ \\
\hline 15. Masco Corporation (MAS) & ISBI & $\begin{array}{l}\text { PRECATORY PROPOSAL PASSED in } \\
2012 \text { ( } 85 \% \text { support); } \\
\text { a precatory proposal was submitted for } \\
\text { the } 2013 \text { annual meeting and agreement } \\
\text { reached; agreed-upon management } \\
\text { declassification proposal received } \\
\text { majority support but did not pass due to } \\
\text { 80\% supermajority requirement. }\end{array}$ \\
\hline 16. Newell Rubbermaid Inc. (NWL) & ISBI & $\begin{array}{l}\text { BOARD DECLASSIFIED after agreed- } \\
\text { upon management declassification } \\
\text { proposal passed in } 2012 \text {. }\end{array}$ \\
\hline 17. Owens Corning (OC) & ISBI & $\begin{array}{l}\text { Agreement reached in 2013; } \\
\text { agreed-upon MANAGEMENT } \\
\text { DECLASSIFICATION PROPOSAL to } \\
\text { go to a vote in } 2014 \text {. }\end{array}$ \\
\hline 18. Owens-Illinois, Inc. (OI) & ISBI & $\begin{array}{l}\text { BOARD DECLASSIFIED after agreed- } \\
\text { upon management declassification } \\
\text { proposal passed in } 2012 \text {. }\end{array}$ \\
\hline 19. Principal Financial Group, Inc. (PFG) & ISBI & $\begin{array}{l}\text { Agreement reached in 2012; } \\
\text { agreed-upon management declassification } \\
\text { proposal received majority support but } \\
\text { did not pass due to } 75 \% \text { supermajority } \\
\text { requirement. }\end{array}$ \\
\hline 20. QEP Resources, Inc. (QEP) & ISBI & $\begin{array}{l}\text { PRECATORY PROPOSAL PASSED in } \\
2012 \text { ( } 88 \% \text { support); } \\
\text { a precatory proposal was submitted for } \\
\text { the } 2013 \text { annual meeting and agreement } \\
\text { reached; agreed-upon management } \\
\text { declassification proposal received } \\
\text { majority support but did not pass due to } \\
\text { 80\% supermajority requirement. }\end{array}$ \\
\hline
\end{tabular}




\begin{tabular}{|c|c|c|c|}
\hline 21. & Quest Diagnostics Incorporated (DGX) & ISBI & $\begin{array}{l}\text { PRECATORY PROPOSAL PASSED in } \\
2012 \text { (94\% support); } \\
\text { company subsequently announced } \\
\text { management declassification proposal } \\
\text { going to a vote in 2013; BOARD } \\
\text { DECLASSIFIED after the company’s } \\
\text { announced management declassification } \\
\text { proposal passed in } 2013 .\end{array}$ \\
\hline 22. & St. Jude Medical, Inc. (STJ) & ISBI & $\begin{array}{l}\text { Agreed-upon management } \\
\text { declassification proposal in } 2012 \text { received } \\
\text { majority support but did not pass due to } \\
80 \% \text { supermajority requirement; } \\
\text { a precatory proposal was submitted for } \\
\text { the } 2013 \text { annual meeting and agreement } \\
\text { reached; agreed-upon management } \\
\text { declassification proposal received } \\
\text { majority support but did not pass due to } \\
80 \% \text { supermajority requirement. }\end{array}$ \\
\hline 23. & The Progressive Corporation (PGR) & ISBI & $\begin{array}{l}\text { BOARD DECLASSIFIED after agreed- } \\
\text { upon management declassification } \\
\text { proposal passed in } 2012 \text {. }\end{array}$ \\
\hline 24. & United Natural Foods, Inc. (UNFI) & ISBI & $\begin{array}{l}\text { BOARD DECLASSIFIED after } \\
\text { agreed-upon management } \\
\text { declassification proposal passed in } \\
2013 .\end{array}$ \\
\hline 25. & Urban Outfitters, Inc. (URBN) & ISBI & $\begin{array}{l}\text { PRECATORY PROPOSAL PASSED in } \\
2012 \text { ( } 60 \% \text { support); } \\
\text { BOARD DECLASSIFIED by subsequent } \\
\text { board-adopted bylaw amendment. }\end{array}$ \\
\hline 26. & US Airways Group, Inc. (LCC) & ISBI & $\begin{array}{l}\text { Agreement reached in 2013; } \\
\text { agreed-upon MANAGEMENT } \\
\text { DECLASSIFICATION PROPOSAL } \\
\text { to go to a vote in } 2014 .\end{array}$ \\
\hline 27. & Vornado Realty Trust (VNO) & ISBI & $\begin{array}{l}\text { PRECATORY PROPOSAL PASSED in } \\
2012 \text { (86\% support); } \\
\text { PRECATORY PROPOSAL PASSED in } \\
2013 \text { (84\% support). }\end{array}$ \\
\hline
\end{tabular}




\begin{tabular}{|l|l|l|}
\hline 28. Vulcan Materials Company (VMC) & ISBI & $\begin{array}{l}\text { PRECATORY PROPOSAL PASSED in } \\
2012 \text { (73\% support); }\end{array}$ \\
& & $\begin{array}{l}\text { a precatory proposal was submitted for } \\
\text { the } 2013 \text { annual meeting and agreement } \\
\text { reached; agreed-upon management } \\
\text { declassification proposal received } \\
\text { majority support but did not pass due to } \\
\end{array}$ \\
& & $80 \%$ supermajority requirement. \\
\hline
\end{tabular}

\section{B. Outcomes of all 2012 \& 2013 Proposals by LACERA}

\begin{tabular}{|c|c|c|c|}
\hline & Company & Proponent & Outcome/Current Status \\
\hline & Airgas, Inc. (ARG) & LACERA & $\begin{array}{l}\text { PRECATORY PROPOSAL PASSED in } \\
2012 \text { (64\% support); } \\
\text { PRECATORY PROPOSAL PASSED in } \\
2013 \text { ( } 57 \% \text { support). }\end{array}$ \\
\hline & Autoliv, Inc. (ALV) & LACERA & $\begin{array}{l}\text { Agreement reached in 2013; } \\
\text { agreed-upon MANAGEMENT } \\
\text { DECLASSIFICATION PROPOSAL to go } \\
\text { to a vote in } 2014 .\end{array}$ \\
\hline 3 & CareFusion Corporation (CFN) & $\begin{array}{l}\text { LACERA } \\
\text { (submitted } \\
\text { 2012) }\end{array}$ & $\begin{array}{l}\text { PRECATORY PROPOSAL PASSED in } \\
2012 \text { (91\% support); } \\
\text { BOARD DECLASSIFIED after agreed- } \\
\text { upon management declassification } \\
\text { proposal passed in } 2013 \text {. }\end{array}$ \\
\hline & CF Industries Holdings, Inc. (CF) & LACERA & $\begin{array}{l}\text { PRECATORY PROPOSAL PASSED in } \\
2012 \text { (93\% support); } \\
\text { Company subsequently announced } \\
\text { management declassification proposal } \\
\text { going to a vote in 2013; BOARD } \\
\text { DECLASSIFIED after agreed-upon } \\
\text { management declassification proposal } \\
\text { passed in } 2013 .\end{array}$ \\
\hline & Citrix Systems, Inc. (CTXS) & LACERA & $\begin{array}{l}\text { Agreement reached in 2012; } \\
\text { BOARD DECLASSIFIED after agreed- } \\
\text { upon management declassification } \\
\text { proposal passed in } 2013 .\end{array}$ \\
\hline
\end{tabular}




\begin{tabular}{|c|c|c|c|}
\hline & $\begin{array}{l}\text { Cognizant Technology Solutions } \\
\text { Corporation (CTSH) }\end{array}$ & LACERA & $\begin{array}{l}\text { PRECATORY PROPOSAL PASSED in } \\
2012 \text { ( } 91 \% \text { support); } \\
\text { a precatory proposal was submitted for the } \\
2013 \text { annual meeting and agreement } \\
\text { reached; BOARD DECLASSIFIED after } \\
\text { agreed-upon management declassification } \\
\text { proposal passed in } 2013 \text {. }\end{array}$ \\
\hline 7. & $\begin{array}{l}\text { DENTSPLY International Inc. } \\
\text { (XRAY) }\end{array}$ & LACERA & $\begin{array}{l}\text { PRECATORY PROPOSAL PASSED in } \\
2012 \text { ( } 78 \% \text { support); } \\
\text { a precatory proposal was submitted for the } \\
2013 \text { annual meeting and agreement } \\
\text { reached; BOARD DECLASSIFIED after } \\
\text { agreed-upon management declassification } \\
\text { proposal passed in } 2013 \text {. }\end{array}$ \\
\hline 8. & McDonald's Corporation (MCD) & LACERA & $\begin{array}{l}\text { BOARD DECLASSIFIED after agreed- } \\
\text { upon management declassification } \\
\text { proposal passed in } 2012 \text {. }\end{array}$ \\
\hline 9. & $\begin{array}{l}\text { MetroPCS Communications, Inc. } \\
\text { (PCS) }\end{array}$ & LACERA & $\begin{array}{l}\text { Agreement reached in 2012; } \\
\text { BOARD DECLASSIFIED after agreed- } \\
\text { upon management declassification } \\
\text { proposal passed in } 2013 \text {. }\end{array}$ \\
\hline 10. & Netflix, Inc. (NFLX) & $\begin{array}{l}\text { LACERA } \\
\text { (submitted } \\
\text { 2012) }\end{array}$ & $\begin{array}{l}\text { PRECATORY PROPOSAL PASSED in } \\
2012 \text { ( } 75 \% \text { support); } \\
\text { a precatory proposal was submitted for the } \\
2013 \text { annual meeting and PASSED ( } 88 \% \\
\text { support). }\end{array}$ \\
\hline 11. & Perrigo Company (PRGO) & LACERA & $\begin{array}{l}\text { Precatory proposal was submitted for } \\
\text { 2013; after the company agreed to move } \\
\text { toward declassification the company } \\
\text { merged and the newly created company } \\
\text { provides for a declassified board. }\end{array}$ \\
\hline 12. & $\begin{array}{l}\text { Pioneer Natural Resources Company } \\
\text { (PXD) }\end{array}$ & LACERA & $\begin{array}{l}\text { BOARD DECLASSIFIED after agreed- } \\
\text { upon management declassification } \\
\text { proposal passed in } 2012 \text {. }\end{array}$ \\
\hline & Red Hat, Inc. (RHT) & LACERA & $\begin{array}{l}\text { PRECATORY PROPOSAL PASSED in } \\
2012 \text { (95\% support); } \\
\text { a precatory proposal was submitted for the } \\
2013 \text { annual meeting and agreement } \\
\text { reached; BOARD DECLASSIFIED after } \\
\text { agreed-upon management declassification } \\
\text { proposal passed in } 2013 \text {. }\end{array}$ \\
\hline
\end{tabular}




\begin{tabular}{|c|c|c|}
\hline 14. $\quad$ Roper Industries, Inc. (ROP) & LACERA & $\begin{array}{l}\text { Agreement reached in 2012; } \\
\text { agreed-upon MANAGEMENT } \\
\text { DECLASSIFICATION PROPOSAL going } \\
\text { to a vote in } 2013 .\end{array}$ \\
\hline 15. The J. M. Smucker Company (SJM) & LACERA & $\begin{array}{l}\text { PRECATORY PROPOSAL PASSED in } \\
2012 \text { ( } 77 \% \text { support); } \\
\text { a precatory proposal was submitted for the } \\
2013 \text { annual meeting and agreement } \\
\text { reached; BOARD DECLASSIFIED after } \\
\text { agreed-upon management declassification } \\
\text { proposal passed in } 2013 .\end{array}$ \\
\hline 16. Unum Group (UNM) & LACERA & $\begin{array}{l}\text { Agreement reached in 2012; } \\
\text { BOARD DECLASSIFIED after agreed- } \\
\text { upon management declassification } \\
\text { proposal passed in } 2013 .\end{array}$ \\
\hline 17. $\quad$ WESCO International, Inc. (WCC) & LACERA & $\begin{array}{l}\text { PRECATORY PROPOSAL PASSED in } \\
2013 \text { ( } 88 \% \text { support). }\end{array}$ \\
\hline
\end{tabular}

\section{Outcomes of all 2012 \& 2013 Proposals by NCF}

\begin{tabular}{|c|c|c|c|}
\hline & Company & Proponent & Outcome/Current Status \\
\hline & Amphenol Corporation (APH) & NCF & $\begin{array}{l}\text { BOARD DECLASSIFIED after agreed- } \\
\text { upon management declassification } \\
\text { proposal passed in } 2012 \text {. }\end{array}$ \\
\hline & Baxter International Inc. (BAX) & NCF & $\begin{array}{l}\text { PRECATORY PROPOSAL PASSED in } \\
2012 \text { (99\% support); a precatory proposal } \\
\text { was submitted for the } 2013 \text { annual meeting } \\
\text { and agreement reached; agreed-upon } \\
\text { management declassification proposal in } \\
2013 \text { did not pass due to a supermajority } \\
\text { requirement. }\end{array}$ \\
\hline & Best Buy Co, Inc. (BBY) & NCF & $\begin{array}{l}\text { PRECATORY PROPOSAL PASSED in } \\
2012 \text { (97\% support); } \\
\text { Company subsequently announced } \\
\text { management declassification proposal } \\
\text { going to a vote in 2013; BOARD } \\
\text { DECLASSIFIED after agreed-upon } \\
\text { management declassification proposal } \\
\text { passed in } 2013 .\end{array}$ \\
\hline & BorgWarner Inc. (BWA) & NCF & $\begin{array}{l}\text { PRECATORY PROPOSAL PASSED in } \\
2013 \text { (99\% support). }\end{array}$ \\
\hline
\end{tabular}




\begin{tabular}{|c|c|c|c|}
\hline & $\begin{array}{l}\text { C.H. Robinson Worldwide, Inc. } \\
\text { (CHRW) }\end{array}$ & NCF & $\begin{array}{l}\text { BOARD DECLASSIFIED after agreed- } \\
\text { upon management declassification } \\
\text { proposal passed in } 2012 \text {. }\end{array}$ \\
\hline 6. & CareFusion Corporation (CFN) & $\begin{array}{l}\text { NCF } \\
\text { (submitted } \\
\text { 2013) }\end{array}$ & $\begin{array}{l}\text { PRECATORY PROPOSAL PASSED } \\
\text { in } 2012 \text { (91\% support); } \\
\text { BOARD DECLASSIFIED after } \\
\text { agreed-upon management } \\
\text { declassification proposal passed in } \\
2013 .\end{array}$ \\
\hline 7. & CarMax, Inc. (KMX) & NCF & $\begin{array}{l}\text { PRECATORY PROPOSAL PASSED in } \\
2012 \text { ( } 87 \% \text { support); } \\
\text { a precatory proposal was submitted for the } \\
2013 \text { annual meeting and agreement } \\
\text { reached; BOARD DECLASSIFIED after } \\
\text { agreed-upon management declassification } \\
\text { proposal passed in } 2013 .\end{array}$ \\
\hline 8. & Eli Lilly and Company (LLY) & NCF & $\begin{array}{l}\text { Agreed-upon management declassification } \\
\text { proposal in } 2012 \text { received majority support } \\
\text { but did not pass due to } 80 \% \text { supermajority } \\
\text { requirement. }\end{array}$ \\
\hline 9. & FLIR Systems, Inc. (FLIR) & NCF & $\begin{array}{l}\text { PRECATORY PROPOSAL PASSED in } \\
2012 \text { ( } 82 \% \text { support); } \\
\text { a precatory proposal was submitted for the } \\
2013 \text { annual meeting and agreement } \\
\text { reached; BOARD DECLASSIFIED after } \\
\text { agreed-upon management declassification } \\
\text { proposal passed in } 2013 .\end{array}$ \\
\hline 10. & FMC Corporation (FMC) & NCF & $\begin{array}{l}\text { PRECATORY PROPOSAL PASSED in } \\
2012 \text { ( } 83 \% \text { support); } \\
\text { a precatory proposal was submitted for the } \\
2013 \text { annual meeting and agreement } \\
\text { reached; BOARD DECLASSIFIED after } \\
\text { agreed-upon management declassification } \\
\text { proposal passed in } 2013 .\end{array}$ \\
\hline 11. & GameStop Corp. (GME) & NCF & $\begin{array}{l}\text { Agreement reached in 2012; } \\
\text { BOARD DECLASSIFIED after agreed- } \\
\text { upon management declassification } \\
\text { proposal passed in } 2013 .\end{array}$ \\
\hline & Hudson City Bancorp, Inc. (HCBK) & NCF & $\begin{array}{l}\text { BOARD DECLASSIFIED after agreed- } \\
\text { upon management declassification } \\
\text { proposal passed in } 2012 \text {. }\end{array}$ \\
\hline
\end{tabular}




\begin{tabular}{|c|c|c|c|}
\hline & $\begin{array}{l}\text { Marathon Petroleum Corporation } \\
\text { (MPC) }\end{array}$ & NCF & $\begin{array}{l}\text { Agreed-upon management declassification } \\
\text { proposal in } 2013 \text { received majority support } \\
\text { but did not pass due to } 80 \% \text { supermajority } \\
\text { requirement. }\end{array}$ \\
\hline 14. & Moody's Corporation (MCO) & NCF & $\begin{array}{l}\text { PRECATORY PROPOSAL PASSED in } \\
2012 \text { ( } 77 \% \text { support); } \\
\text { a precatory proposal was submitted for the } \\
2013 \text { annual meeting and agreement } \\
\text { reached; BOARD DECLASSIFIED after } \\
\text { agreed-upon management declassification } \\
\text { proposal passed in } 2013 \text {. }\end{array}$ \\
\hline 15. & O'Reilly Automotive, Inc. (ORLY) & NCF & $\begin{array}{l}\text { Agreement reached in 2012; } \\
\text { BOARD DECLASSIFIED after agreed- } \\
\text { upon management declassification } \\
\text { proposal passed in } 2013 .\end{array}$ \\
\hline 16. & salesforce.com, inc. (CRM) & NCF & $\begin{array}{l}\text { PRECATORY PROPOSAL PASSED in } \\
2012 \text { ( } 81 \% \text { support); } \\
\text { a precatory proposal was submitted for the } \\
2013 \text { annual meeting and agreement } \\
\text { reached; BOARD DECLASSIFIED after } \\
\text { agreed-upon management declassification } \\
\text { proposal passed in } 2013 \text {. }\end{array}$ \\
\hline 17. & TECO Energy, Inc. (TE) & NCF & $\begin{array}{l}\text { BOARD DECLASSIFIED after agreed- } \\
\text { upon management declassification } \\
\text { proposal passed in } 2012 \text {. }\end{array}$ \\
\hline 18. & The Western Union Company (WU) & NCF & $\begin{array}{l}\text { BOARD DECLASSIFIED after agreed- } \\
\text { upon management declassification } \\
\text { proposal passed in } 2012 \text {. }\end{array}$ \\
\hline & V. F. Corporation (VFC) & NCF & $\begin{array}{l}\text { PRECATORY PROPOSAL PASSED in } \\
2012 \text { (63\% support); } \\
\text { BOARD DECLASSIFIED by subsequent } \\
\text { board-adopted bylaw amendment. }\end{array}$ \\
\hline 20. & $\begin{array}{l}\text { Wyndham Worldwide Corporation } \\
\text { (WYN) }\end{array}$ & NCF & $\begin{array}{l}\text { BOARD DECLASSIFIED after agreed- } \\
\text { upon management declassification } \\
\text { proposal passed in } 2012 \text {. }\end{array}$ \\
\hline & Xylem Inc. (XYL) & NCF & $\begin{array}{l}\text { BOARD DECLASSIFIED after agreed- } \\
\text { upon management declassification } \\
\text { proposal passed in } 2013 \text {. }\end{array}$ \\
\hline
\end{tabular}




\section{Outcomes of all 2012 \& 2013 Proposals by NCDST}

\begin{tabular}{|c|c|c|c|}
\hline & Company & Proponent & Outcome/Current Status \\
\hline 1. & Alcoa Inc. (AA) & NCDST & $\begin{array}{l}\text { Agreed-upon management declassification } \\
\text { proposal in } 2012 \text { received majority support } \\
\text { but did not pass due to } 80 \% \text { supermajority } \\
\text { requirement. }\end{array}$ \\
\hline 2. & Bemis Company, Inc. (BMS) & NCDST & $\begin{array}{l}\text { PRECATORY PROPOSAL PASSED in } \\
2012 \text { (75\% support); } \\
\text { BOARD DECLASSIFIED by subsequent } \\
\text { board-adopted bylaw amendment. }\end{array}$ \\
\hline 3. & Cabot Oil \& Gas Corporation (COG) & NCDST & $\begin{array}{l}\text { BOARD DECLASSIFIED after agreed- } \\
\text { upon management declassification } \\
\text { proposal passed in } 2012 \text {. }\end{array}$ \\
\hline 4. & $\begin{array}{l}\text { Cameron International Corporation } \\
\text { (CAM) }\end{array}$ & NCDST & $\begin{array}{l}\text { BOARD DECLASSIFIED after agreed- } \\
\text { upon management declassification } \\
\text { proposal passed in } 2012 \text {. }\end{array}$ \\
\hline 5. & Flowserve Corporation (FLS) & NCDST & $\begin{array}{l}\text { BOARD DECLASSIFIED after agreed- } \\
\text { upon management declassification } \\
\text { proposal passed in } 2012 \text {. }\end{array}$ \\
\hline 6. & FMC Technologies, Inc. (FTI) & NCDST & $\begin{array}{l}\text { BOARD DECLASSIFIED after agreed- } \\
\text { upon management declassification } \\
\text { proposal passed in } 2012 \text {. }\end{array}$ \\
\hline 7. & Foot Locker, Inc. (FL) & NCDST & $\begin{array}{l}\text { PRECATORY PROPOSAL PASSED in } \\
2013 \text { (91\% support). }\end{array}$ \\
\hline 8. & Helmerich \& Payne (HP) & NCDST & $\begin{array}{l}\text { BOARD DECLASSIFIED after agreed- } \\
\text { upon management declassification } \\
\text { proposal passed in } 2012 \text {. }\end{array}$ \\
\hline 9. & Hess Corporation (HES) & NCDST & $\begin{array}{l}\text { PRECATORY PROPOSAL PASSED in } \\
2012 \text { ( } 78 \% \text { support); } \\
\text { a precatory proposal was submitted for the } \\
2013 \text { annual meeting and agreement } \\
\text { reached; BOARD DECLASSIFIED after } \\
\text { agreed-upon management declassification } \\
\text { proposal passed in } 2013 .\end{array}$ \\
\hline & Intuitive Surgical, Inc. (ISRG) & NCDST & $\begin{array}{l}\text { BOARD DECLASSIFIED after agreed- } \\
\text { upon management declassification } \\
\text { proposal passed in } 2012 \text {. }\end{array}$ \\
\hline & Janus Capital Group Inc. (JNS) & NCDST & $\begin{array}{l}\text { BOARD DECLASSIFIED after agreed- } \\
\text { upon management declassification } \\
\text { proposal passed in } 2012 \text {. }\end{array}$ \\
\hline
\end{tabular}




\begin{tabular}{|c|c|c|c|}
\hline 12. & Jarden Corporation (JAH) & NCDST & $\begin{array}{l}\text { PRECATORY PROPOSAL PASSED in } \\
2013 \text { (88\% support). }\end{array}$ \\
\hline & Kellogg Company (K) & NCDST & $\begin{array}{l}\text { Precatory proposal did not pass; } \\
\text { a precatory proposal was submitted for the } \\
2013 \text { annual meeting and PASSED (52\% } \\
\text { support). }\end{array}$ \\
\hline 14. & $\begin{array}{l}\text { L-3 Communications Holdings, Inc. } \\
\text { (LLL) }\end{array}$ & NCDST & $\begin{array}{l}\text { BOARD DECLASSIFIED after agreed- } \\
\text { upon management declassification } \\
\text { proposal passed in } 2013 \text {. }\end{array}$ \\
\hline 15. & Lexmark International, Inc. (LXK) & NCDST & $\begin{array}{l}\text { PRECATORY PROPOSAL PASSED in } \\
2012 \text { (93\% support); } \\
\text { a precatory proposal was submitted for the } \\
2013 \text { annual meeting and agreement } \\
\text { reached; BOARD DECLASSIFIED after } \\
\text { agreed-upon management declassification } \\
\text { proposal passed in } 2013 \text {. }\end{array}$ \\
\hline 16. & $\begin{array}{l}\text { MEMC Electronic Materials, Inc. } \\
\text { (WFR) }\end{array}$ & NCDST & $\begin{array}{l}\text { PRECATORY PROPOSAL PASSED in } \\
2012 \text { (96\% support); } \\
\text { Company subsequently announced } \\
\text { management declassification proposal } \\
\text { going to a vote in 2013; BOARD } \\
\text { DECLASSIFIED after the company’s } \\
\text { announced management declassification } \\
\text { proposal passed in } 2013 \text {. }\end{array}$ \\
\hline & NRG Energy, Inc. (NRG) & NCDST & $\begin{array}{l}\text { BOARD DECLASSIFIED after agreed- } \\
\text { upon management declassification } \\
\text { proposal passed in } 2012 \text {. }\end{array}$ \\
\hline & PACCAR Inc. (PCAR) & NCDST & $\begin{array}{l}\text { Precatory proposal did not pass in } 2012 \text {; } \\
\text { a precatory proposal was submitted for the } \\
2013 \text { annual meeting and did not pass. }\end{array}$ \\
\hline & $\begin{array}{l}\text { People's United Financial, Inc. } \\
\text { (PBCT) }\end{array}$ & NCDST & $\begin{array}{l}\text { PRECATORY PROPOSAL PASSED in } \\
2012 \text { (91\% support); } \\
\text { a precatory proposal was submitted for the } \\
2013 \text { annual meeting and agreement } \\
\text { reached; BOARD DECLASSIFIED after } \\
\text { agreed-upon management declassification } \\
\text { proposal passed in } 2013 \text {. }\end{array}$ \\
\hline
\end{tabular}




\begin{tabular}{|c|c|c|}
\hline 20. $\quad$ PPG Industries, Inc. (PPG) & NCDST & $\begin{array}{l}\text { Agreed-upon management declassification } \\
\text { proposal in } 2012 \text { received majority support } \\
\text { but did not pass due to } 80 \% \text { supermajority } \\
\text { requirement; } \\
\text { a precatory proposal was submitted for the } \\
2013 \text { annual meeting and agreement } \\
\text { reached; agreed-upon management } \\
\text { declassification proposal received majority } \\
\text { support but did not pass due to } 80 \% \\
\text { supermajority requirement. }\end{array}$ \\
\hline 21. Rowan Companies, Inc. (RDC) & NCDST & $\begin{array}{l}\text { BOARD DECLASSIFIED after agreed- } \\
\text { upon management declassification } \\
\text { proposal passed in } 2012 \text {. }\end{array}$ \\
\hline 22. $\quad$ Ryder System, Inc. (R) & NCDST & $\begin{array}{l}\text { PRECATORY PROPOSAL PASSED in } \\
2012 \text { ( } 88 \% \text { support); } \\
\text { a precatory proposal was submitted for the } \\
2013 \text { annual meeting and agreement } \\
\text { reached; BOARD DECLASSIFIED after } \\
\text { agreed-upon management declassification } \\
\text { proposal passed in } 2013 .\end{array}$ \\
\hline 23. $\quad$ SCANA Corporation (SCG) & $\begin{array}{l}\text { NCDST } \\
\text { (submitted } \\
\text { 2012) }\end{array}$ & $\begin{array}{l}\text { PRECATORY PROPOSAL PASSED in } \\
2012 \text { (60\% support); } \\
\text { a precatory proposal was submitted for the } \\
2013 \text { annual meeting and PASSED ( } 70 \% \\
\text { support). }\end{array}$ \\
\hline 24. Snap-On Incorporated (SNA) & NCDST & $\begin{array}{l}\text { PRECATORY PROPOSAL PASSED in } \\
2012 \text { ( } 85 \% \text { support); } \\
\text { a precatory proposal was submitted for the } \\
2013 \text { annual meeting and agreement } \\
\text { reached; BOARD DECLASSIFIED after } \\
\text { agreed-upon management declassification } \\
\text { proposal passed in 2013. }\end{array}$ \\
\hline 25. Stanley Black \& Decker, Inc. (SWK) & NCDST & $\begin{array}{l}\text { BOARD DECLASSIFIED after agreed- } \\
\text { upon management declassification } \\
\text { proposal passed in } 2012 \text {. }\end{array}$ \\
\hline 26. $\quad$ Teradata Corporation (TDC) & NCDST & $\begin{array}{l}\text { Agreed-upon management declassification } \\
\text { proposal in } 2012 \text { received majority support } \\
\text { but did not pass due to } 80 \% \text { supermajority } \\
\text { requirement; } \\
\text { PRECATORY PROPOSAL PASSED in } \\
2013 \text { (99\% support). }\end{array}$ \\
\hline
\end{tabular}




\begin{tabular}{|l|l|l|}
\hline 27. United States Steel Corporation (X) & NCDST & PRECATORY PROPOSAL PASSED in \\
& & 2012 (82\% support); \\
& & PRECATORY PROPOSAL PASSED in \\
& & 2013 (81\% support). \\
\hline
\end{tabular}

\section{E. Outcomes of all 2012 \& 2013 Proposals by OPERS}

\begin{tabular}{|c|c|c|c|}
\hline & Company & Proponent & Outcome/Current Status \\
\hline 1. & $\begin{array}{l}\text { Allegheny Technologies Incorporated } \\
\text { (ATI) }\end{array}$ & OPERS & $\begin{array}{l}\text { Agreement reached in 2012; agreed-upon } \\
\text { MANAGEMENT DECLASSIFICATION } \\
\text { PROPOSAL going to a vote in } 2014 .\end{array}$ \\
\hline 2 & C.R. Bard, Inc. (BCR) & OPERS & $\begin{array}{l}\text { BOARD DECLASSIFIED after agreed- } \\
\text { upon management declassification } \\
\text { proposal passed in } 2012 \text {. }\end{array}$ \\
\hline 3 & CIGNA Corporation (CI) & OPERS & $\begin{array}{l}\text { Agreed-upon management declassification } \\
\text { proposal received majority support but did } \\
\text { not pass due to } 80 \% \text { supermajority } \\
\text { requirement; } \\
\text { BOARD DECLASSIFIED by subsequent } \\
\text { board-adopted bylaw amendment. }\end{array}$ \\
\hline 4 & EQT Corporation (EQT) & OPERS & $\begin{array}{l}\text { PRECATORY PROPOSAL PASSED in } \\
2012 \text { (81\% support); } \\
\text { a precatory proposal was submitted for the } \\
2013 \text { annual meeting and agreement } \\
\text { reached; BOARD DECLASSIFIED after } \\
\text { agreed-upon management declassification } \\
\text { proposal passed in } 2013 \text {. }\end{array}$ \\
\hline 5 & Tellabs, Inc. (TLAB) & OPERS & $\begin{array}{l}\text { Agreement reached in 2012; } \\
\text { agreed-upon management declassification } \\
\text { proposal in } 2013 \text { received majority support } \\
\text { but did not pass due to } 75 \% \text { supermajority } \\
\text { requirement. }\end{array}$ \\
\hline 6 & The Mosaic Company (MOS) & OPERS & $\begin{array}{l}\text { Agreement reached in 2013; } \\
\text { agreed-upon MANAGEMENT } \\
\text { DECLASSIFICATION PROPOSAL to } \\
\text { go to a vote in } 2014 \text {. }\end{array}$ \\
\hline
\end{tabular}




\section{F. Outcomes of all 2012 \& 2013 Proposals by PRIM}

\begin{tabular}{|c|c|c|}
\hline Company & Proponent & Outcome/Current Status \\
\hline $\begin{array}{l}\text { 1. Air Products and Chemicals, Inc. } \\
\text { (APD) }\end{array}$ & PRIM & $\begin{array}{l}\text { PRECATORY PROPOSAL PASSED in } \\
2013 \text { (80\% support); } \\
\text { Company announced plan to bring } \\
\text { management declassification proposal to a } \\
\text { vote in } 2014 \text {. }\end{array}$ \\
\hline 2. $\quad$ Ashland Inc. (ASH) & PRIM & $\begin{array}{l}\text { PRECATORY PROPOSAL PASSED in } \\
2013 \text { (83\% support); } \\
\text { company announced plan to bring } \\
\text { management declassification proposal to a } \\
\text { vote in } 2014 \text {. }\end{array}$ \\
\hline $\begin{array}{ll}\text { 3. } & \text { Costco Wholesale Corporation } \\
(\mathrm{COST})\end{array}$ & PRIM & $\begin{array}{l}\text { PRECATORY PROPOSAL PASSED in } \\
2013 \text { ( } 72 \% \text { support); } \\
\text { company announced plan to bring } \\
\text { management declassification proposal to a } \\
\text { vote in } 2014 \text {. }\end{array}$ \\
\hline 4. $\quad$ DeVRY, Inc. (DV) & PRIM & $\begin{array}{l}\text { BOARD DECLASSIFIED after agreed- } \\
\text { upon management declassification } \\
\text { proposal passed in } 2012 \text {. }\end{array}$ \\
\hline 5. JDS Uniphase Corporation (JDSU) & PRIM & $\begin{array}{l}\text { BOARD DECLASSIFIED after agreed- } \\
\text { upon management declassification } \\
\text { proposal passed in } 2012 \text {. }\end{array}$ \\
\hline Jacobs Engineering Group Inc. (JEC) & PRIM & $\begin{array}{l}\text { PRECATORY PROPOSAL PASSED in } \\
2013 \text { ( } 82 \% \text { support); } \\
\text { company announced plan to bring } \\
\text { management declassification proposal to a } \\
\text { vote in } 2014 \text {. }\end{array}$ \\
\hline 7. Johnson Controls, Inc. (JCI) & PRIM & $\begin{array}{l}\text { BOARD DECLASSIFIED after agreed- } \\
\text { upon management declassification } \\
\text { proposal passed in } 2013 \text {. }\end{array}$ \\
\hline KLA-Tencor Corporation (KLAC) & PRIM & $\begin{array}{l}\text { BOARD DECLASSIFIED after agreed- } \\
\text { upon management declassification } \\
\text { proposal passed in } 2012 \text {. }\end{array}$ \\
\hline 9. $\quad$ Monsanto Company (MON) & PRIM & $\begin{array}{l}\text { BOARD DECLASSIFIED after agreed- } \\
\text { upon management declassification } \\
\text { proposal passed in } 2013 \text {. }\end{array}$ \\
\hline 10. $\quad$ Patterson Companies, Inc. (PDCO) & PRIM & $\begin{array}{l}\text { BOARD DECLASSIFIED after agreed- } \\
\text { upon management declassification } \\
\text { proposal passed in } 2012 \text {. }\end{array}$ \\
\hline
\end{tabular}




\begin{tabular}{|c|c|c|}
\hline 11. Rockwell Collins, Inc. (COL) & PRIM & $\begin{array}{l}\text { PRECATORY PROPOSAL PASSED in } \\
2013 \text { (83\% support); } \\
\text { company announced plan to bring } \\
\text { management declassification proposal to a } \\
\text { vote in } 2014 \text {. }\end{array}$ \\
\hline 12. Varian Medical Systems, Inc. (VAR) & PRIM & $\begin{array}{l}\text { PRECATORY PROPOSAL PASSED in } \\
2013 \text { (75\% support); } \\
\text { company announced plan to bring } \\
\text { management declassification proposal to a } \\
\text { vote in } 2014 \text {. }\end{array}$ \\
\hline
\end{tabular}

\section{G. Outcomes of all 2012 \& 2013 Proposals by SBA}

\begin{tabular}{|cll|l|l|}
\hline \multicolumn{2}{|c|}{ Company } & Proponent & Outcome/Current Status \\
\hline 1. & Huntsman Corporation (HUN) & SBA & $\begin{array}{l}\text { PRECATORY PROPOSAL PASSED in } \\
\text { 2013 (59\% support). }\end{array}$ \\
\hline 2. & Manpower Inc. (MAN) & SBA & $\begin{array}{l}\text { BOARD DECLASSIFIED after agreed- } \\
\text { upon management declassification } \\
\text { proposal passed in 2013. }\end{array}$ \\
\hline 3. & NCR Corporation (NCR) & SBA & $\begin{array}{l}\text { PRECATORY PROPOSAL PASSED in } \\
\text { 2013 (80\% support). }\end{array}$ \\
\hline $4 . \quad$ Netflix, Inc. (NFLX) & $\begin{array}{l}\text { SBA } \\
\text { (submitted } \\
\text { 2013) }\end{array}$ & $\begin{array}{l}\text { PRECATORY PROPOSAL PASSED in } \\
\text { 2012 (75\% support); } \\
\text { a precatory proposal was submitted for the } \\
\text { 2013 annual meeting and PASSED (88\% } \\
\text { support). }\end{array}$ \\
\hline 5. & NII Holdings, Inc. (NIHD) & SBA & $\begin{array}{l}\text { BOARD DECLASSIFIED after agreed- } \\
\text { upon management declassification } \\
\text { proposal passed in 2013. }\end{array}$ \\
\hline $6 . \quad$ SPX Corporation (SPW) & $\begin{array}{l}\text { Agreed-upon management declassification } \\
\text { proposal in 2013 received majority support } \\
\text { but did not pass due to 80\% supermajority } \\
\text { requirement. }\end{array}$ \\
\hline
\end{tabular}

\section{H. Outcomes of all 2012 \& 2013 Proposals by SERS}

\begin{tabular}{|cl|l|l|}
\hline \multicolumn{2}{|c|}{ Company } & Proponent & Outcome/Current Status \\
\hline 1. & $\begin{array}{l}\text { Crown Castle International Corp. } \\
(\mathrm{CCI})\end{array}$ & SERS & $\begin{array}{l}\text { BOARD DECLASSIFIED after agreed- } \\
\text { upon management declassification } \\
\text { proposal passed in 2013. }\end{array}$ \\
\hline 2. & Lincoln National Corporation (LNC) & SERS & $\begin{array}{l}\text { BOARD DECLASSIFIED by board- } \\
\text { adopted bylaw amendment. }\end{array}$ \\
\hline
\end{tabular}




\begin{tabular}{|c|c|c|}
\hline $\begin{array}{ll}\text { 3. } & \text { Reinsurance Group of America, } \\
\text { Incorporated (RGA) }\end{array}$ & SERS & $\begin{array}{l}\text { Agreed-upon management declassification } \\
\text { proposal in } 2013 \text { received majority support } \\
\text { but did not pass due to } 85 \% \text { supermajority } \\
\text { requirement. }\end{array}$ \\
\hline 4. $\quad$ SCANA Corporation (SCG) & $\begin{array}{l}\text { SERS } \\
\text { (submitted } \\
\text { 2013) }\end{array}$ & $\begin{array}{l}\text { PRECATORY PROPOSAL PASSED in } \\
2012 \text { (60\% support); } \\
\text { a precatory proposal was submitted for the } \\
2013 \text { annual meeting and PASSED ( } 70 \% \\
\text { support). }\end{array}$ \\
\hline 5. Tech Data Corporation (TECD) & SERS & $\begin{array}{l}\text { Agreement reached in 2013; } \\
\text { agreed-upon MANAGEMENT } \\
\text { DECLASSIFICATION PROPOSAL to go } \\
\text { to a vote at the coming annual meeting } \\
\text { (which has been postponed from 2013). }\end{array}$ \\
\hline
\end{tabular}

